\title{
Sedimentary characteristics and origin of the Late Pleistocene Ice Complex on north-east Siberian Arctic coastal lowlands and islands - A review
}

\author{
L. Schirrmeister ${ }^{\mathrm{a}, *}$, V. Kunitsky ${ }^{\mathrm{b}}$, G. Grosse ${ }^{\mathrm{c}}$, S. Wetterich ${ }^{\mathrm{a}}$, H. Meyer ${ }^{\mathrm{a}}$, G. Schwamborn ${ }^{\mathrm{a}}$, O. Babiy ${ }^{\mathrm{b}}$, \\ A. Derevyagin ${ }^{\mathrm{d}}$, C. Siegert ${ }^{\mathrm{a}}$ \\ ${ }^{a}$ Alfred Wegener Institute for Polar and Marine Research, Periglacial Research, Telegrafenberg A 43, 14471 Potsdam, Germany \\ ${ }^{\mathrm{b}}$ Melnikov Permafrost Institute RAS SB, Merslotnaya Street, Yakutsk, Republic of Sakha, (Yakutia), 677010 Russia

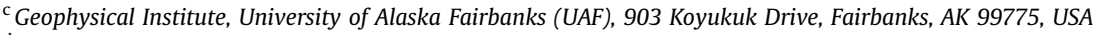 \\ ${ }^{\mathrm{d}}$ Moscow State University (MSU), Faculty of Geology Russia, Moscow 119899, Vorobievy Gory
}

\section{A R T I C L E I N F O}

\section{Article history:}

Available online $\mathrm{xxx}$

\begin{abstract}
A B S T R A C T
The origin of Late Pleistocene ice-rich, fine-grained permafrost sequences (Ice Complex deposits) in arctic and subarctic Siberia has been in dispute for a long time. Corresponding permafrost sequences are frequently exposed along seacoasts and river banks in Yedoma hills, which are considered to be erosional remnants of Late Pleistocene accumulation plains. Detailed cryolithological, sedimentological, geochronological, and stratigraphical results from 14 study sites along the Laptev and East Siberian seacoasts were summarized for the first time in order to compare and correlate the local datasets on a large regional scale. The sediments of the Ice Complex are characterized by poorly-sorted silt to fine-sand, buried cryosols, TOC contents of $1.2-4.8 \mathrm{wt} \%$, and very high ground ice content ( $40-60 \mathrm{wt} \%$ absolute). A second large constituent of the Ice Complex are large syngenetic ice wedges, resulting in a total ice content of the Ice Complex of up to 80 vol\%. Ice Complex deposits were mostly formed during the Middle Weichselian interstadial and/or during the Late Weichselian stadial periods. A conceptual model of nival lithogenesis of Ice Complex deposits was developed that integrates various other formation hypotheses. A combination of various local and regional paleogeographical, geological, and paleoclimate conditions controlled the formation of Ice Complex sequences during the Late Pleistocene in northern East Siberia. They are chronologically and stratigraphically, but not genetically equivalent to Eurasian and Alaskan loess deposits.
\end{abstract}

(c) 2010 Elsevier Ltd and INQUA. All rights reserved.

\section{Introduction}

In Siberia, perennially frozen fine-grained deposits are considered to be part of the Northern Hemisphere Late Pleistocene loess region (Péwé et al., 1977; Péwé and Journaux, 1983; Kaplina and Lozhkin, 1984; Pye, 1984; Frenzel et al., 1992; Colinvaux, 1996; Morozova and Velichko, 1996). The sedimentological and cryolithological genesis of these widely distributed ice-rich sediments is still under discussion, and several hypotheses have been put forward in the last decades. Concepts included ice-sheet-dammed basin sediments (Grosswald, 1998), deltaic formations (Nagaoka et al., 1995), alluvial genesis (Rozenbaum, 1981), proluvial and slope deposits (Gravis, 1969; Slagoda, 2004), cryogenic-aeolian deposits (Tomirdiaro, 1982, 1984; Tomirdiaro and Chernen'k'ii, 1987), nival deposits

\footnotetext{
* Corresponding author.

E-mail address: lutz.schirrmeister@awi.de (L. Schirrmeister).
}

(Kunitsky, 1989; Galabala, 1997), and polygenetic origins (Konishchev, 1981; Sher et al., 1987). Subsequently, some of these hypotheses were easily discarded as the increasing availability of paleoenvironmental data falsified the core ideas of such hypotheses, e.g. the ice-sheetdammed hypothesis of Grosswald (1998) or the deltaic origin of Nagaoka et al. (1995). Currently, the hypothesis of a pure aeolian (loessic) origin of these deposits appears to be the one favoured by most of the current scientific literature (e.g. Brigham-Grette, 2001; Walter et al., 2006; Zimov et al., 2006; Schuur et al., 2008). The concept of a uniform arctic loess cover during the Late Pleistocene is also used in some climate models to simulate a dust cover on snow and ice, which reduces albedo (Krinner et al., 2006). Often, studies on these fine-grained permafrost deposits draw generalized conclusions from few study sites and tend to neglect some of the special paleoenvironmental conditions in heterogeneous periglacial landscapes during the time of deposition.

Permafrost is a widely distributed, climatically-induced phenomenon in terrestrial arctic and subarctic regions. In northern

1040-6182/\$ - see front matter (c) 2010 Elsevier Ltd and INQUA. All rights reserved. doi:10.1016/j.quaint.2010.04.004 
East Siberia, permafrost is closely connected to long-term stable cold and dry climate conditions and the absence of large ice sheets in the Quaternary past (Hubberten et al., 2004). Extreme cooling under the influence of long-term very cold winter air temperatures resulted in the formation and preservation of a thick continuous permafrost zone. Areas where such conditions prevailed for several 10,000 year periods during the Late Pleistocene include the arctic lowland regions east of the Eurasian ice shield. The idea of largely barren and windswept North Siberian lowlands prone to wind-erosion and acting as both source and sink of loessic material during the Late Pleistocene has been largely discarded by newer paleoenvironmental studies indicating a nearly complete vegetation cover and dense populations of grazing animals (e.g. Sher et al., 2003, 2005).

The fine-grained Late Pleistocene ice-rich deposits in question, called Ice Complex formations (in Russian: ledovyi complex, according to Soloviev, 1959), are well exposed along coasts and river banks in the northern East Siberian lowlands. For describing this permafrost formation, the term "Yedoma" is very often used synonymously (e.g. Zimov et al., 2006). In its original sense, the term Yedoma defines relief features in East Siberian lowlands, i.e. elevated areas separating thermokarst depressions (Kolosov, 1947; Baranova and Biské, 1964; Tomirdiaro, 1980; Mursaev, 1984). Such hills are usually composed of the Ice Complex deposits. Because of the high content of fossil plant and animal remains ranging from grass leaves to mammoth bones, and the unknown depositional origin, these deposits had already attracted scientific interest early in the 19th century (Adams, 1807; Bunge, 1895).

Ice Complex deposits are an essential component of periglacial landscapes in the northern East Siberian lowlands, and play an important role for understanding the Late Pleistocene sedimentological, stratigraphical, and paleoenvironmental dynamics in East Siberia. In connection with ongoing climate change and global warming, it is assumed that the Ice Complex formations will be transformed from a long-term carbon sink to a major carbon source as these organic-rich sediments thaw and greenhouse gases are subsequently released (Walter et al., 2006; Zimov et al., 2006; Schuur et al., 2008).

This study presents similarities and differences among various Ice Complex sequences by summarizing cryolithological data acquired and analyzed within the Russian-German science collaboration "Laptev Sea System" from 1998 to 2008. Short descriptions of geomorphological, stratigraphical, and cryolithological features are presented for 14 major sites (Fig. 1) and then summarized into five different Ice Complex provinces. Selected records of similar sedimentological parameters are used for the synthesis. The objective of this paper is to provide a comprehensive characterisation of Ice Complex deposits in northern East Siberia, i.e., for the Laptev Sea region and the New Siberian Archipelago. Ice Complex genesis is discussed and the conceptual model of deposition and genesis for these deposits is advanced by going a step beyond the prevailing loess formation hypothesis.

Although site-specific data has been published before in numerous papers (Table 1 ), a generalizing review of Ice Complex characteristics from NE Siberian Arctic coastal lowland and island sites was not conducted yet. This paper represents the first systematic review of ten years of intense cryolithological field studies on North Siberian Ice Complex deposits.

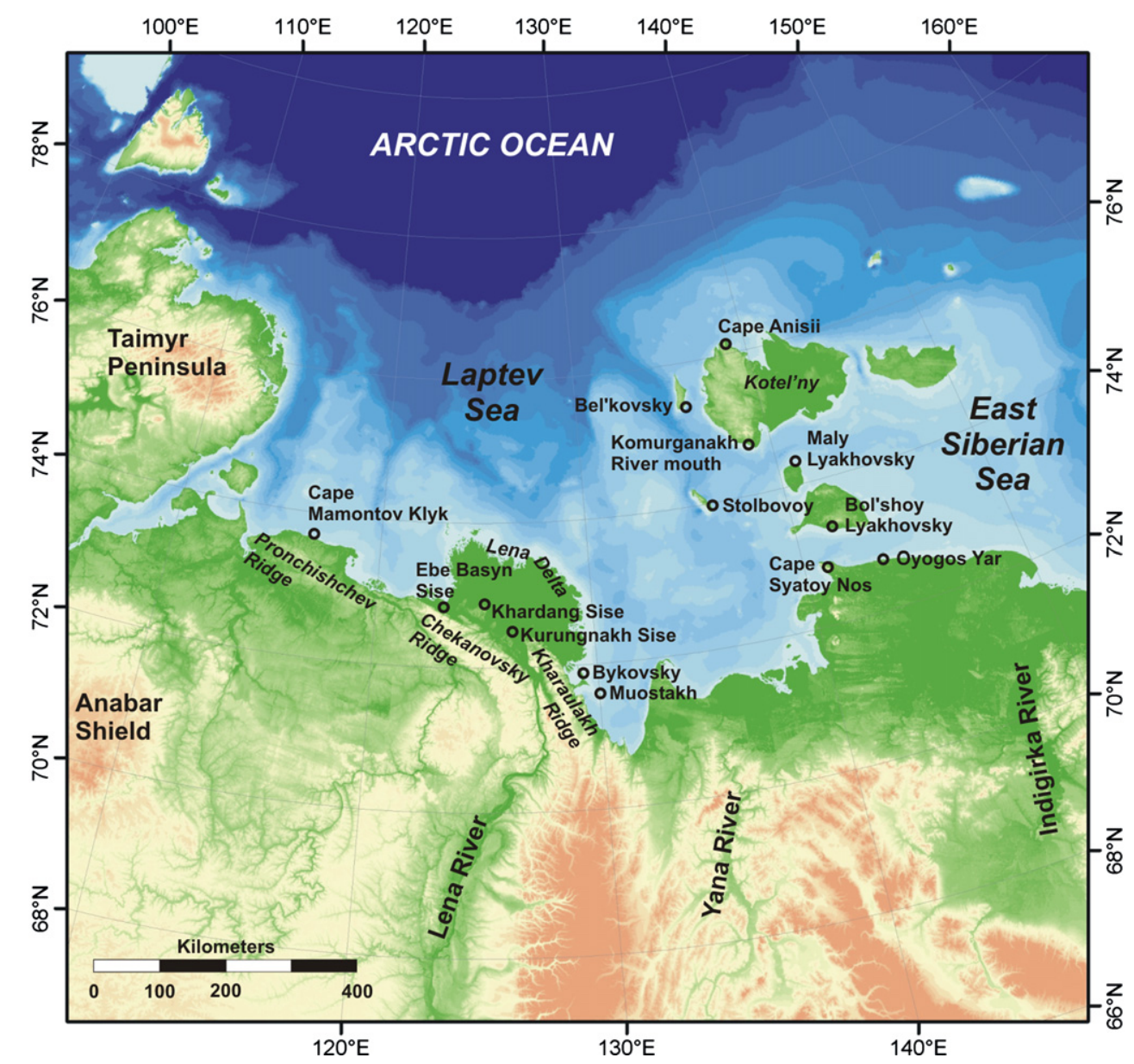

Fig. 1. Study region in northern East Siberia and positions of study sites and other locations mentioned in the text. 
Table 1

Location of studied Ice Complex sites indicated in Fig. 1 and corresponding site-specific publications.

\begin{tabular}{|c|c|c|c|}
\hline \multirow[t]{2}{*}{ Region } & \multirow[t]{2}{*}{ Location } & \multicolumn{2}{|c|}{ Coordinates } \\
\hline & & ${ }^{\circ} \mathrm{N}$ & ${ }^{\circ} \mathrm{E}$ \\
\hline W Laptev Sea & $\begin{array}{l}\text { Cape Mamontov Klyk (Schirrmeister et al., 2008; Bobrov et al., 2009; Müller et al., 2009; } \\
\text { Winterfeld et al., under review) }\end{array}$ & 73.61 & 117.18 \\
\hline \multirow[t]{3}{*}{ Lena Delta } & Ebe Basyn Sise Island (Nagym) & 72.88 & 123.32 \\
\hline & Khardang Sise Island, 2005 (Schirrmeister, 2007) & 72.95 & 124.21 \\
\hline & $\begin{array}{l}\text { Kurungnakh Sise Island (Buor Khaya), 1998, 2000, } 2002 \text { (Kuzmina et al., 2003; Schirrmeister } \\
\text { et al. 2001, 2003b; Schwamborn et al., 1999, 2002; Wetterich et al., 2008) }\end{array}$ & 72.33 & 126.30 \\
\hline \multirow[t]{2}{*}{ E Laptev Sea } & $\begin{array}{l}\text { Bykovsky Peninsula (Mamontovy Khayata), 1998, } 2002 \text { (Siegert } \\
\text { et al., 1999, 2002; Sher et al., 2000, 2005; Andreev et al., 2002; Meyer } \\
\text { et al, 2002a; Schirrmeister 2002a,b; Grosse et al., 2003, 2005, 2007; } \\
\text { Bobrov et al., 2004; Kienast et al., 2005; Wetterich et al., 2005) }\end{array}$ & 71.78 & 128.42 \\
\hline & Muostakh Island, 2002 (Schirrmeister et al., 2003a) & 71.61 & 129.94 \\
\hline New Siberian & Stolbovoy Island, 2002 (Schirrmeister et al., 2003a) & 74.06 & 136.08 \\
\hline \multirow[t]{5}{*}{ Archipelago } & Bel'kovsky Island, 2002 (Schirrmeister et al., 2003a) & 75.37 & 135.59 \\
\hline & N Kotelny Island (Cape Anisii), 2002 (Schirrmeister et al., 2003a) & 76.17 & 139.01 \\
\hline & SW Kotelny Island (Komurganakh River mouth), 2002 (Schirrmeister et al., 2003a) & 74.73 & 138.45 \\
\hline & Maly Lyakhovsky Island, 2002 (Schirrmeister et al., 2003a) & 74.25 & 140.35 \\
\hline & $\begin{array}{l}\text { Bol'shoy Lyakhovsky Island (Zimov'e River), 1999, } 2007 \text { (Schirrmeister } \\
\text { et al., 2000, 2003a, 2008b; Meyer et al., 2002b; Andreev et al., 2004, 2009; } \\
\text { Ilyashuk et al., 2006; Schirrmeister et al., 2008b; Kienast } \\
\text { et al., 2008; Wetterich et al., 2009) }\end{array}$ & 73.30 & 141.5 \\
\hline Dmitry Laptev & Cape Syatoy Nos, 1999 & 72.84 & 140.85 \\
\hline Strait & $\begin{array}{l}\text { Oyogos Yar coast, 2002, } 2007 \text { (Schirrmeister et al., 2003a, 2008b; Wetterich } \\
\text { et al., 2009) }\end{array}$ & 72.68 & 143.53 \\
\hline
\end{tabular}

\section{Geographical setting}

Ice Complex deposits are widely distributed in the coastal lowlands of the Laptev, East Siberian, and Chukchi seas, on the New Siberian Archipelago, and in other continental lowlands and large river valleys of East Siberia, especially in Yakutia (Fig. 1; Romanovsky, 1993; Walter et al., 2007). The Ice Complex is a characteristic feature in the stratigraphy and landscapes of the western part of the Beringian landmass which is described as the extended non-glaciated region between the Eurasian and the Laurentian ice shields during the Late Pleistocene.

The sites are well exposed large bluffs on the coast of the Laptev Sea, the Dmitry Laptev Strait, the New Siberian Islands, and along river cutbanks in the Lena Delta (Figs. 1 and 2; Table 1). The study sites are part of the arctic and subarctic tundra zones, and are underlain by continuous permafrost several hundreds of meters deep (Yershov, 1989). A continental arctic climate with long severe winters and short cold summers is typical for the region today.

The study region belongs to the Arctic Rift Zone, characterized by vertical block tectonics with narrow long horsts, grabens and synclines and a high modern seismic activity (Grigoriev et al., 1996; Drachev et al., 1998; Imaev et al., 2000; Franke et al., 2000). Coastal lowlands in the western part of the study region are framed by small mountain ridges of $200-500 \mathrm{~m}$ asl (above sea level) like the Pronchishchev Ridge, the Chekanovky Ridge and the Kharaulakh Range. They belong to the Olenek Zone and the Late Mesozoic folded sediment complex between the Siberian Craton and the Laptev Paraplatformal Block. These low ridges are considered the north-western continuation of the Verkhoyan Mountain Range (Drachev et al., 1998). In the eastern part of the study region isolated bedrock elevations of Cretaceous granite domes exist as well as the fold ranges on Kotel'ny Island.

\section{Methods}

Although the steep permafrost outcrops are generally well exposed, it is often necessary to study accessible subsections and then to combine these subsections into complete vertical profiles.
Limiting factors for accessibility are steepness of bluffs, overhanging frozen sediments and peat, and extensive mudflows from melting ground ice. Subsections consist of sediment sequences deposited in ice wedge polygon centres exposed between ice wedges on the bluffs or in still-frozen, undisturbed thermokarst mounds in front of a bluff (Fig. 2). Vertical position and thickness of stratigraphic horizons in such exposures were surveyed using laser theodolite and measuring tapes. The initial stratigraphic assessment of the frozen sediments included descriptions of colour, organic remains, sediment type, and cryostructures. Each subsection was sampled in $0.5-1.0 \mathrm{~m}$ intervals. About $500 \mathrm{~g}$ of frozen sediment was collected per sample and sealed in plastic bags. The gravimetric ice content was determined in the field laboratory as the ratio of the weight of ice in a sample to the weight of the dry sample and expressed as weight percentage (wt \%) (van Everdingen, 1998). Ice contents were not measured for all samples but representatively for ca. every third sample in each subprofile.

In the laboratory, sediment samples were freeze-dried, homogenized, and split into subsamples. For grain size analysis, subsamples were first treated with hydrogen peroxide to remove organic matter and then measured in a laser particle analyser (Coulter LS 200). The software SEDIVISION was used to obtain the grain size mean and sorting parameters. The mass-specific mineral magnetic susceptibility (MS) was measured with a Bartington MS2 and an MS2B-type sensor. The values of MS are expressed in SI units $\left(10^{-8} \mathrm{~m}^{3} \mathrm{~kg}^{-1}\right)$. The contents of total organic carbon (TOC), total carbon (TC), and total nitrogen (TN) were measured with a CNS analyser (Elementar Vario EL III). The C/N ratio is calculated as the quotient of TOC and TN values. This ratio was only calculated when the $\mathrm{TN}$ values are $>0.05 \%$. The carbonate (inorganic carbon) content was calculated by subtracting TOC from TC. Stable carbon isotope composition $\left(\delta^{13} \mathrm{C}\right)$ of TOC (contents $>0.3 \%$ ) was measured with a Finnigan DELTA $S$ mass spectrometer. The values are expressed in delta per mil notation $(\delta, \%)$ relative to the Vienna Pee Dee Belemnite (VPDB) Standard. The $63-125 \mu \mathrm{m}$ subfraction of selected samples was used for heavy mineral analyses. The grains were gravitationally separated 

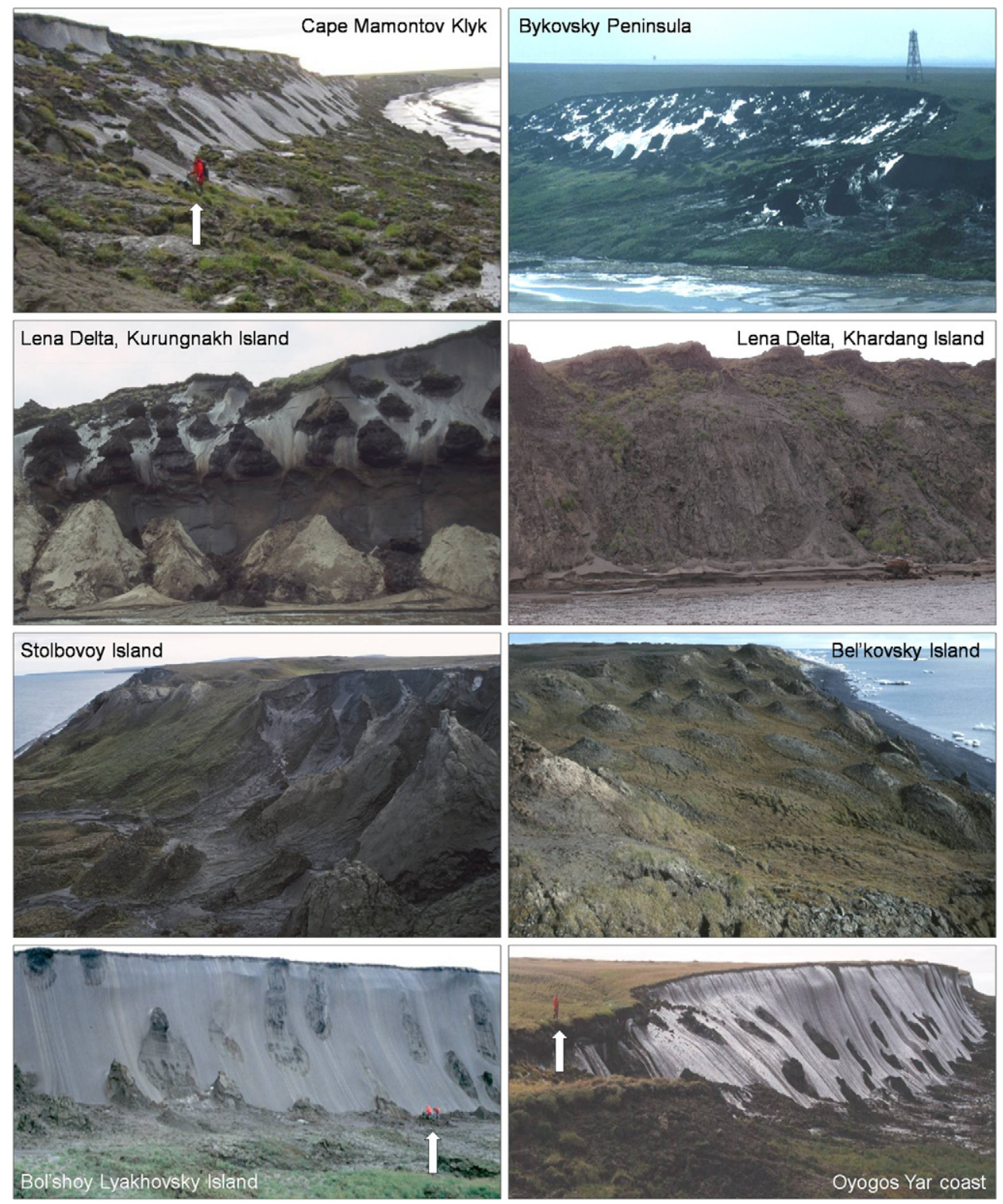

Fig. 2. Photos of Ice Complex exposures studied along the North Siberian coasts. For scale see standing person in some photos (white arrows).

by sodium metatungstate solution (density $2.89 \mathrm{~g} \mathrm{~cm}^{-3}$ ). For each sample three to four hundred grains were identified on microscope slides under polarized light and grain type percentages were calculated.

Selected plant remains were radiocarbon-dated using the accelerator mass spectrometry (AMS) facilities at the Leibniz Laboratory for Radiometric Dating and Stable Isotope Research (Kiel University, Germany). In this laboratory the background inherent to the spectrometer is reduced, which results in low background count rates of the detector, allowing an apparent age of up to $75 \mathrm{ka}$ BP (gated background) (Nadeau et al., 1997, 1998; Grootes, 2004). Many dates used in this reviewing study have been published in previous, site-specific publications and are therefore not listed in this paper. Only new, previously unpublished radiocarbon data from the study region are summarized in Table 2. Underlain deposits below the Ice Complex were mostly dated by optical or infrared stimulated luminescence dating methods (e.g. Krbetschek et al., 2002) and by ${ }^{230} \mathrm{Th} / \mathrm{U}$ dating (e.g. Schirrmeister et al., 2002c).

\section{Results}

\subsection{Cape Mamontov Klyk (Western Laptev Sea)}

The study area is part of a flat ( $<1^{\circ}$ inclination) and about $40 \mathrm{~km}$ wide sedimentary coastal plain north of the Pronchishchev Ridge at the western Laptev Sea coast. The low mountains and hills $(<300 \mathrm{~m}$ asl) are composed of Mesozoic sandstones and siltstones. The coastal plain around Cape Mamontov Klyk is shaped by Yedoma hills that are $20-40 \mathrm{~m}$ asl in height. They are separated by $10-20 \mathrm{~m}$ deep thermo-erosional valleys and thermokarst depressions (alases) with numerous thermokarst lakes. About $78 \%$ of the lowland area is impacted to some degree by thermokarst (Grosse et al., 2006). Ice Complex deposits and the adjacent horizons were studied in two composite profiles in the vicinity of the cape east of the Nuchcha-Dzhiele River mouth in August 2003 (Schirrmeister et al., 2004, 2008a,b).

The Ice Complex sequence is underlain by sandy and peaty fluvial and floodplain deposits of Early to Middle Weichselian ages 
Table 2

Previously unpublished non-calibrated radiocarbon ages of various Ice Complex exposures.

\begin{tabular}{|c|c|c|c|c|}
\hline Lab. no. & Sample & Description & $\begin{array}{l}\text { Height } \\
{[\mathrm{m} \text { asl] }}\end{array}$ & $\begin{array}{l}\text { Radiocarbon } \\
\text { ages } \\
\text { [years BP] }\end{array}$ \\
\hline \multicolumn{5}{|c|}{ Khardang Sise Island } \\
\hline KIA 31029 & Kha-2-1 & Peat inclusion & 3.1 & $>43,550$ \\
\hline KIA 31030 & Kha-2-3 & Peat inclusion & 4.3 & $>49,030$ \\
\hline KIA 31031 & Kha-2-7 & Peat moss & 5.0 & $>52,090$ \\
\hline KIA 31032 & Kha-2-13 & Peat & 6.6 & $>50,200$ \\
\hline KIA 31033 & Kha-2-18 & Plant fragments & 8.6 & $29,770 \pm 250$ \\
\hline KIA 31034 & Kha-2-24 & Wood fragments & 10.1 & $28,050 \pm 190$ \\
\hline KIA 31035 & Kha-2-32 & Plant remains & 16.9 & $20,100 \pm 100$ \\
\hline \multicolumn{5}{|c|}{ Muostakh Island } \\
\hline KIA 25718 & Muo-3-1 & Plant remains & 0.5 & $39,110+2220 /-1740$ \\
\hline KIA 25720 & Muo-3-5 & Twigs & 1.0 & $46,780+1270 /-1100$ \\
\hline KIA 25719 & Muo-3-4 & Twigs, moss & 2.0 & $42,800+980 /-870$ \\
\hline KIA 25721 & Muo-3-8 & Plant remains & 5.0 & $38,620+1310 /-1120$ \\
\hline KIA 25722 & Muo-3-9 & Carex, eriophorum & 7.5 & $40,340+820 /-740$ \\
\hline KIA 25723 & Muo-3-11 & Twigs & 9.7 & $19,560 \pm 80$ \\
\hline \multicolumn{5}{|c|}{ Stolbovoy Island } \\
\hline KIA 26279 & STO-1-6 & Twigs, betula nana & 27 & $>50,890$ \\
\hline KIA 26280 & STO-2-1 & Plant remains & 10 & $>40,830$ \\
\hline KIA 26281 & STO 2-2 & Plant remains & 1 & $>36,440$ \\
\hline KIA 26282 & STO 2-3 & Twigs & 3 & $>52,250$ \\
\hline KIA 26283 & STO-3-1 & Moss & 5 & $>42,430$ \\
\hline KIA 26284 & STO-3-5 & Moss & 6 & $>54,940$ \\
\hline KIA 26285 & STO-3-8 & Twigs, moss & 6.75 & $36,580+2070 /-1640$ \\
\hline KIA 26286 & STO-4-0 & Moss & 10 & $4480 \pm 40^{a}$ \\
\hline \multicolumn{5}{|c|}{ Bel'kovsky Island } \\
\hline KIA 26287 & BEL-2-1 & Twigs & 2.7 & $54,390+4890 /-3020$ \\
\hline KIA 26288 & BEL-2-6 & Plant stems & 13.7 & $8880 \pm 40^{\mathrm{a}}$ \\
\hline KIA 26289 & BEL-2-7 & Twigs & 14.6 & $8890 \pm 35^{a}$ \\
\hline KIA 26290 & BEL-3-1 & Twigs & 3.7 & $47,660+1890 /-1530$ \\
\hline KIA 26291 & BEL-3-3 & Moss & 4.6 & $>39,840$ \\
\hline KIA 26293 & BEL-7-1 & Twigs & 1.0 & $39,980+900 /-810$ \\
\hline KIA 26194 & BEL-7-3 & Plant remains & 2.5 & $8020 \pm 100^{a}$ \\
\hline KIA 26295 & BEL-7-6 & Plant remains & 3.8 & $8990 \pm 90^{a}$ \\
\hline \multicolumn{5}{|c|}{ N Kotel'ny Island, Cape Anisii } \\
\hline KIA 25738 & Mya-1-1 & $\begin{array}{l}\text { Lemming excrement, } \\
\text { seeds, insect remains }\end{array}$ & $1.5 \mathrm{~m}$ depth & $27,860 \pm 210$ \\
\hline \multicolumn{5}{|c|}{ SW Kotel'ny Island, Khomurganakh River mouth } \\
\hline KIA 25741 & Kys-2-4 & Plant remains & 2.7 & $45,960+2480 /-1880$ \\
\hline KIA 25742 & Kys-2-5 & Plant remains & 3.0 & $52,280+3800 /-2570$ \\
\hline KIA 25743 & Kys-2-6 & Moss & 4.0 & $52,790+4110 /-2710$ \\
\hline KIA 25744 & Kys-2-10 & Plant remains & 8.4 & $35,370+1190 /-1030$ \\
\hline \multicolumn{5}{|c|}{ Maly Lyakhovsky Island, Cape Vaygach } \\
\hline KIA 26300 & KLY-1-1 & Moss & $5.0 \mathrm{~m}$ depth & $>38,290$ \\
\hline KIA 26301 & KLY-1-4 & Plant remains & $3.3 \mathrm{~m}$ depth & $34,680+5380 /-3200$ \\
\hline KIA 26302 & KLY-1-9 & Twigs & $1.5 \mathrm{~m}$ depth & $27,980+250 /-240$ \\
\hline \multicolumn{5}{|c|}{ Cape Svyatoy Nos } \\
\hline KIA 12517 & X-99-019 & Plant remains & 14.6 & $>47,640$ \\
\hline KIA 12518 & $\mathrm{X}-99-014$ & Plant remains & 9.6 & $45,350+4370 /-2820$ \\
\hline KIA 12516 & $\mathrm{X}-99-024$ & Plant remains & 17.0 & $>50,290$ \\
\hline KIA 12515 & $\mathrm{X}-99-025$ & Plant remains & 24.0 & $36,080+530 /-490$ \\
\hline \multicolumn{5}{|c|}{ Oyogos Yar coast } \\
\hline KIA 37630 & Оy7-08-32 & Plant remains & 9.5 & $41,420+1040 /-920$ \\
\hline KIA 37631 & Оy7-08-37 & Peat inclusion & 12.0 & $43,860+1270 /-1090$ \\
\hline KIA 37632 & Оy7-08-38 & Peat inclusion & 15.5 & $44,840+1270 /-1100$ \\
\hline KIA 37633 & Оy7-08-42 & Plant remains & 17.1 & $48,540+1750 /-1440$ \\
\hline KIA 37634 & Оy7-08-47 & Plant remains & 19.2 & $40,850+1750 / 1440$ \\
\hline KIA 37635 & Оy7-08-53 & Peat inclusion & 22.0 & $44,900+1230 /-1060$ \\
\hline KIA 37636 & Оy7-08-57 & Plant remains & 24.0 & $38,600+930 /-830$ \\
\hline KIA 37637 & Оy7-08-62 & Grass roots & 26.5 & $34,630+420 /-400$ \\
\hline KIA 37638 & Оy7-08-63 & Grass roots & 27.0 & $32,220+370 /-350$ \\
\hline
\end{tabular}

${ }^{\text {a }}$ Inclusive Holocene cover deposits.

(Overduin et al., 2007; Schirrmeister et al., 2008a). In several places the Ice Complex is covered by small, filled Holocene thermokarst depressions (Fig. 3). In the Ice Complex, syngenetic ice wedges 1-3 $\mathrm{m}$ wide and $10-25 \mathrm{~m}$ high frame $2-4 \mathrm{~m}$ wide sediment columns, which have formed as fillings of low-centred polygonal systems. The transparent, grey to yellowish-white wedge ice is composed of hundreds of ice veins $2-5 \mathrm{~mm}$ wide containing numerous gas bubbles several $\mathrm{mm}$ in diameter. 
E

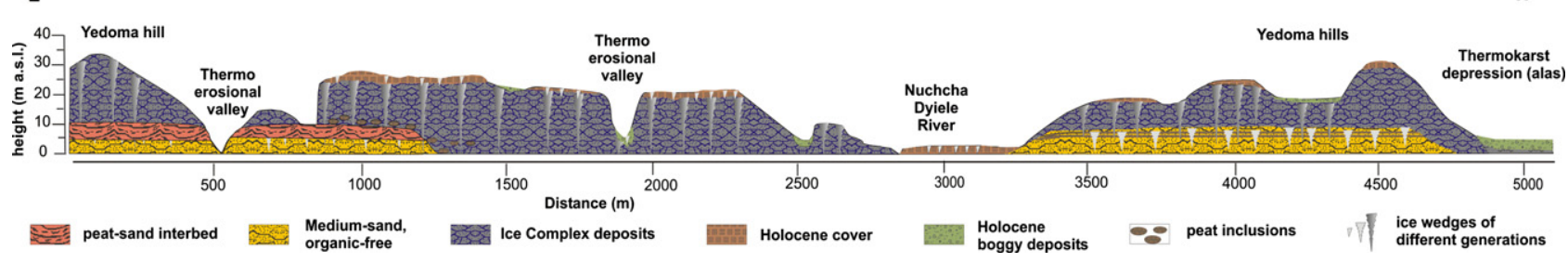

Fig. 3. Generalized cross-section of the exposure at Cape Mamontov Klyk (redrawn after to Schirrmeister et al., 2008a).

The sediment columns of both composite Ice Complex profiles consist of several brownish buried cryosol layers containing many plant fragments, peat inclusions, fine plant detritus, and patches of iron oxide impregnations (SOM $1 \mathrm{E}, \mathrm{F}$ ). The organic-rich soil layers alternate with grey mineral-rich horizons; the alternating layers are $0.2-0.7 \mathrm{~m}$ thick. The cryostructure of the sediment is banded with lens-like reticulations between ice bands. The gravimetric ice content varies between 100 and $250 \mathrm{wt} \%$ for buried cryosol horizons and between 50 and $100 \mathrm{wt} \%$ for mineral-rich layers (Fig. 4). The sediments are poorly sorted, which is indicated by significantly changing ratios of fine to coarse-grained silt fractions and great variability of the fine-grained sand fraction. The mean grain size varies between 10 and $115 \mu \mathrm{m}$. The magnetic susceptibility shows a well correlated linear trend to the exposure height from 15 to $60 \times$ SI $\left(R^{2}=0.71\right)$ perhaps caused by gradually changing transport and accumulation conditions. The Ice Complex deposits contain $0.2-6 \mathrm{wt} \%$ of carbonate. The TOC, $\mathrm{C} / \mathrm{N}$, and $\delta^{13} \mathrm{C}$ values are rather uniform (Fig. 4). Minor variations of these parameters are connected with buried cryosol occurrences. $\delta^{13} \mathrm{C}$ variations in particular are caused by changing qualities of organic matter provenance (i.e. plant remains and/or the decomposition of organic detritus). The analyzed samples are similar in heavy mineral composition. Dominant heavy minerals are epidote, pyroxene, and amphibole. This uniformity indicates a constant sediment source during the period of deposition (Table 3). The available radiocarbon data indicate a continuous accumulation of Ice Complex deposits at Cape Mamontov Klyk between 27.2 and 14.5 ka BP (Schirrmeister et al., 2008a).

The overlying Holocene cover deposits dated from 9.5 to $2.2 \mathrm{ka}$ $\mathrm{BP}$ and clearly differ in various sediment parameters (Fig. 4).

\subsection{Ice Complex sections in the Lena Delta}

Parts of the third delta terrace in the western and southern parts of the Lena River Delta are considered to be remnants of an Ice Complex accumulation plain that formed north of the Chekanovsky Ridge during the Late Pleistocene when the river had its delta much farther north (Schwamborn et al., 2002; Schirrmeister et al., 2003b; Wetterich et al., 2008). The surface of the third terrace reaches elevations of $30-40 \mathrm{~m}$ asl and is dissected by thermokarst

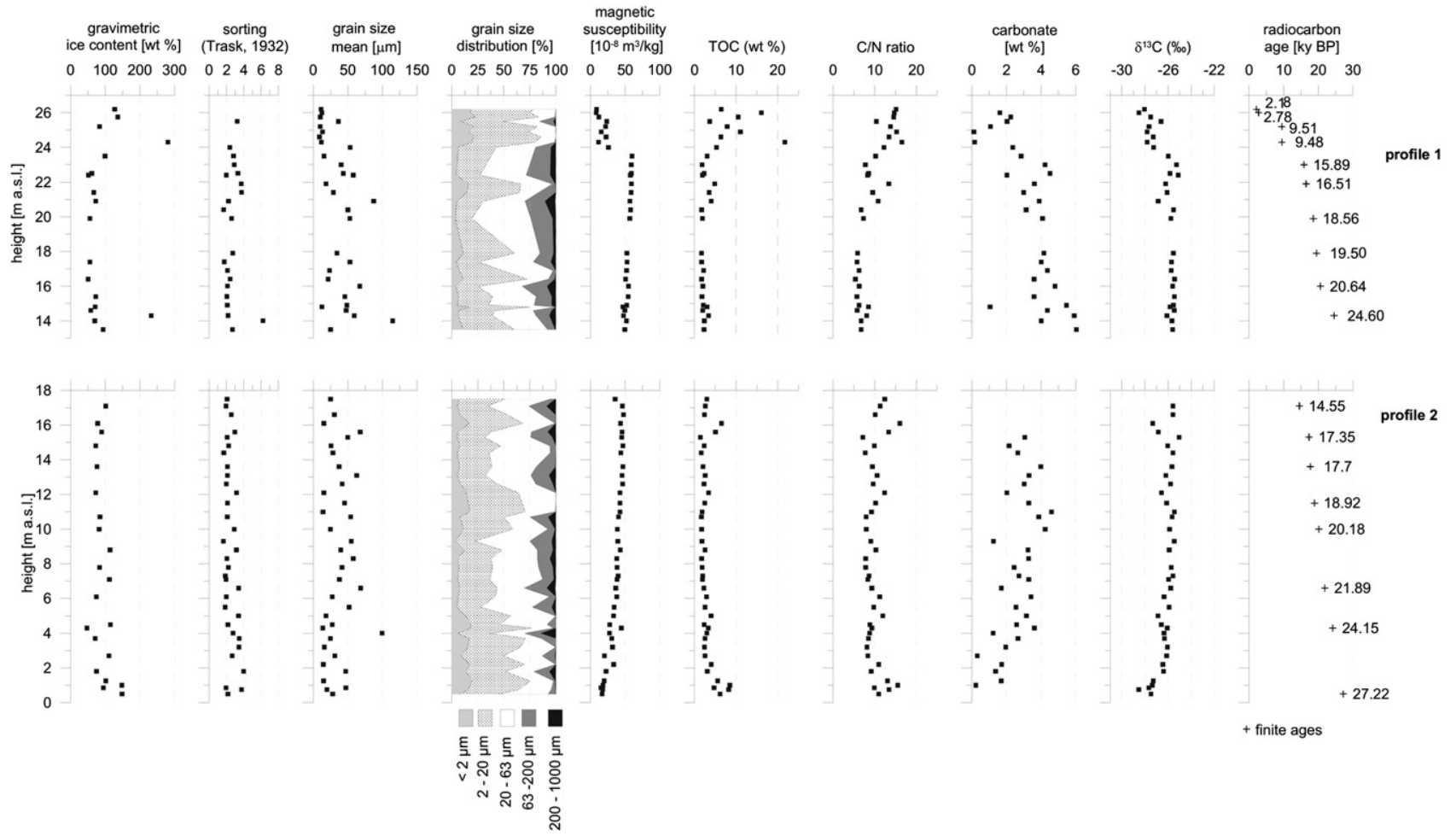

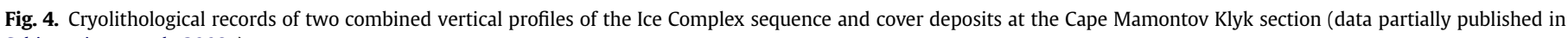
Schirrmeister et al., 2008a). 
Table 3

Heavy mineral composition of several Ice Complex sequences; mean, standard deviation in grain per cent, and number of samples $(n),+$ single grains.

\begin{tabular}{|c|c|c|c|c|c|c|c|}
\hline Minerals & $\begin{array}{l}\text { Cape } \\
\text { Mamontov } \\
\text { Klyk }^{\mathrm{a}}\end{array}$ & $\begin{array}{l}\text { Kurungnakh } \\
\text { Island }{ }^{\mathrm{b}}\end{array}$ & $\begin{array}{l}\text { Bykovsky } \\
\text { Peninsula } \\
\text { Mamontovy } \\
\text { Khayata }^{c}\end{array}$ & $\begin{array}{l}\text { Bel'kovsky } \\
\text { Island }\end{array}$ & $\begin{array}{l}\text { Stolbovoy } \\
\text { Island }\end{array}$ & $\begin{array}{l}\text { Kotel'ny } \\
\text { Island, } \\
\text { Cape Anisii }\end{array}$ & $\begin{array}{l}\text { Bol'shoy } \\
\text { Lyakhovsky }\end{array}$ \\
\hline Ilmenite & $\begin{array}{l}3.6 \pm 1.70 \\
(n=39)\end{array}$ & & $\begin{array}{l}14.2 \pm 4.6 \\
(n=50)\end{array}$ & $\begin{array}{l}1.9 \pm 1.2 \\
(n=4)\end{array}$ & $\begin{array}{l}2.1 \pm 1.3 \\
(n=14)\end{array}$ & $\begin{array}{l}6.0 \pm 3.8 \\
(n=3)\end{array}$ & $\begin{array}{l}2.3 \pm 1.5 \\
(n=11)\end{array}$ \\
\hline Epidote & $\begin{array}{l}17.4 \pm 2.8 \\
(n=39)\end{array}$ & $\begin{array}{l}15.8 \pm 0.6 \\
(n=3)\end{array}$ & $\begin{array}{l}5.3 \pm 2.1 \\
(n=50)\end{array}$ & $\begin{array}{l}14.6 \pm 4.7 \\
(n=5)\end{array}$ & $\begin{array}{l}8.3 \pm 4.6 \\
(n=16)\end{array}$ & $\begin{array}{l}13.7 \pm 1.9 \\
(n=3)\end{array}$ & $\begin{array}{l}16.0 \pm 6.5 \\
(n=11)\end{array}$ \\
\hline Pyroxene & $\begin{array}{l}26.1 \pm 3.76 \\
(n=39)\end{array}$ & $\begin{array}{l}3.0 \pm 0.2 \\
(n=3)\end{array}$ & $\begin{array}{l}49.1 \pm 10 \\
(n=50)\end{array}$ & $\begin{array}{l}9.9 \pm 2.7 \\
(n=5)\end{array}$ & $\begin{array}{l}3.7 \pm 2.3 \\
(n=16)\end{array}$ & $\begin{array}{l}19.0 \pm 3.4 \\
(n=3)\end{array}$ & $\begin{array}{l}8.6 \pm 4.4 \\
(n=12)\end{array}$ \\
\hline Amphibole & $\begin{array}{l}34.7 \pm 3.78 \\
(n=39)\end{array}$ & $\begin{array}{l}14.4 \pm 2.1 \\
(n=3)\end{array}$ & $\begin{array}{l}11.8 \pm 5.3 \\
(n=50)\end{array}$ & $\begin{array}{l}31.6 \pm 9.3 \\
(n=5)\end{array}$ & $\begin{array}{l}16.0 \pm 9.7 \\
(n=16)\end{array}$ & $\begin{array}{l}38.4 \pm 0.9 \\
(n=3)\end{array}$ & $\begin{array}{l}40.2 \pm 13.8 \\
(n=12)\end{array}$ \\
\hline Garnet & $\begin{array}{l}4.9 \pm 1.70 \\
(n=39)\end{array}$ & $\begin{array}{l}25.2 \pm 0.3 \\
(n=3)\end{array}$ & $\begin{array}{l}2.8 \pm 1.2 \\
(n=50)\end{array}$ & $\begin{array}{l}2.9 \pm 1.1 \\
(n=5)\end{array}$ & $\begin{array}{l}1.6 \pm 1.2 \\
(n=13)\end{array}$ & $\begin{array}{l}6.0 \pm 0.8 \\
(n=3)\end{array}$ & $\begin{array}{l}2.0 \pm 0.8 \\
(n=10)\end{array}$ \\
\hline Zircon & $\begin{array}{l}0.7 \pm 0.40 \\
(n=30)\end{array}$ & $\begin{array}{l}1.3 \pm 0.5 \\
(n=3)\end{array}$ & $\begin{array}{l}1.4 \pm 0.9 \\
(n=47)\end{array}$ & $\begin{array}{l}0.3 \\
(n=2)\end{array}$ & $\begin{array}{l}0.5 \pm 0.3 \\
(n=12)\end{array}$ & $\begin{array}{l}0.9 \pm 0.3 \\
(n=3)\end{array}$ & $\begin{array}{l}0.9 \pm 0.6 \\
(n=8)\end{array}$ \\
\hline Apatite & $\begin{array}{l}2.6 \pm 0.87 \\
(n=39)\end{array}$ & $\begin{array}{l}7.6 \pm 4.1 \\
(n=3)\end{array}$ & $\begin{array}{l}2.9 \pm 1.5 \\
(n=48)\end{array}$ & $\begin{array}{l}0.6 \pm 0.6 \\
(n=4)\end{array}$ & $\begin{array}{l}0.8 \pm 0.4 \\
(n=11)\end{array}$ & $\begin{array}{l}1.8 \pm 1.2 \\
(n=3)\end{array}$ & $\begin{array}{l}1.7 \pm 1.0 \\
(n=10)\end{array}$ \\
\hline Tourmaline & $\begin{array}{l}0.4 \pm 0.21 \\
(n=28)\end{array}$ & $\begin{array}{l}1.3 \pm 0.5 \\
(n=3)\end{array}$ & $\begin{array}{l}0.6 \pm 0.5 \\
(n=48)\end{array}$ & $\begin{array}{l}0.3 \\
(n=2)\end{array}$ & $\begin{array}{l}0.3 \pm 0.1 \\
(n=3)\end{array}$ & $\begin{array}{l}1.2 \pm 1.2 \\
(n=2)\end{array}$ & $\begin{array}{l}0.6 \pm 0.7 \\
(n=6)\end{array}$ \\
\hline Titanite & $\begin{array}{l}4.1 \pm 1.48 \\
(n=39)\end{array}$ & $\begin{array}{l}1.7 \pm 0.7 \\
(n=3)\end{array}$ & $\begin{array}{l}0.05 \pm 0.17 \\
(n=19)\end{array}$ & $\begin{array}{l}2.1 \pm 1.1 \\
(n=5)\end{array}$ & $\begin{array}{l}1.9 \pm 1.0 \\
(n=15)\end{array}$ & $\begin{array}{l}6.0 \pm 2.0 \\
(n=3)\end{array}$ & $\begin{array}{l}4.0 \pm 2 \\
(n=11)\end{array}$ \\
\hline Leucoxene & $\begin{array}{l}2.2 \pm 0.75 \\
(n=39)\end{array}$ & & $\begin{array}{l}7.5 \pm 2.9 \\
(n=50)\end{array}$ & $\begin{array}{l}0.9 \pm 0.8 \\
(n=5)\end{array}$ & $\begin{array}{l}1.4 \pm 1.2 \\
(n=5)\end{array}$ & $\begin{array}{l}1.4 \pm 0.2 \\
(n=2)\end{array}$ & $\begin{array}{l}4.1 \pm 3.9 \\
(n=11)\end{array}$ \\
\hline Rutil & $\begin{array}{l}0.4 \pm 0.22 \\
(n=18)\end{array}$ & & $\begin{array}{l}0.4 \pm 0.36 \\
(n=28)\end{array}$ & $\begin{array}{l}0.3 \\
(n=1)\end{array}$ & $\begin{array}{l}0.3 \\
(n=4)\end{array}$ & $\begin{array}{l}0.3 \\
(n=2)\end{array}$ & \\
\hline Disthene & $\begin{array}{l}0.3 \pm 0.10 \\
(n=11)\end{array}$ & & $\begin{array}{l}0.16 \pm 0.51 \\
(n=22)\end{array}$ & $\begin{array}{l}0.3 \\
(n=1)\end{array}$ & $\begin{array}{l}+ \\
(n=2)\end{array}$ & $\begin{array}{l}+ \\
(n=3)\end{array}$ & \\
\hline Staurolite & $\begin{array}{l}0.3 \pm 0.14 \\
(n=7)\end{array}$ & & $\begin{array}{l}0.04 \pm 0.13 \\
(n=19)\end{array}$ & & & $\begin{array}{l}0.7 \\
(n=1)\end{array}$ & \\
\hline Andalusite & $\begin{array}{l}0.3 \pm 0.12 \\
(n=8)\end{array}$ & & $\begin{array}{l}0.05 \pm 0.11 \\
(n=19)\end{array}$ & & & & \\
\hline Chloritoid & $\begin{array}{l}0.3 \pm 0.04 \\
(n=4)\end{array}$ & & $\begin{array}{l}0.6 \pm 0.6 \\
(n=4)\end{array}$ & & $\begin{array}{l}0.3 \\
(n=2)\end{array}$ & $\begin{array}{l}+ \\
(n=2)\end{array}$ & \\
\hline Ortite & $\begin{array}{l}0.4 \pm 0.12 \\
(n=6)\end{array}$ & & & & & $\begin{array}{l}0.3 \\
(n=1)\end{array}$ & \\
\hline Silimanite & $\begin{array}{l}0.3 \pm 0.09 \\
(n=3)\end{array}$ & & & & & $\begin{array}{l}0.3 \\
(n=1)\end{array}$ & \\
\hline weathered mica/muscovite & & & & $\begin{array}{l}12.6 \pm 7.9 \\
(n=5)\end{array}$ & $\begin{array}{l}20.5 \pm 10.6 \\
(n=16)\end{array}$ & $\begin{array}{l}0.6 \pm 0.4 \\
(n=2)\end{array}$ & $\begin{array}{l}17.4 \pm 16.4 \\
(n=12)\end{array}$ \\
\hline Biotite & $\begin{array}{l}0.7 \pm 0.56 \\
(n=21)\end{array}$ & & $\begin{array}{l}0.6 \pm 0.5 \\
(n=8)\end{array}$ & $\begin{array}{l}0.3 \\
(n=1)\end{array}$ & $\begin{array}{l}9.5 \pm 8.8 \\
(n=16)\end{array}$ & $\begin{array}{l}0.3 \\
(n=2)\end{array}$ & $\begin{array}{l}1.6 \pm 0.5 \\
(n=6)\end{array}$ \\
\hline Chlorite & $\begin{array}{l}1.6 \pm 1.56 \\
(n=37)\end{array}$ & & $\begin{array}{l}1.0 \pm 0.8 \\
(n=42)\end{array}$ & $\begin{array}{l}0.9 \pm 0.8 \\
(n=5)\end{array}$ & $\begin{array}{l}35.4 \pm 9.4 \\
(n=16)\end{array}$ & $\begin{array}{l}4.5 \pm 0.4 \\
(n=3)\end{array}$ & $\begin{array}{l}4.0 \pm 3.6 \\
(n=12)\end{array}$ \\
\hline Corundum & & $\begin{array}{l}0.7 \pm 0.6 \\
(n=3)\end{array}$ & & & & & \\
\hline Zoisite & & $\begin{array}{l}7.5 \pm 4.1 \\
(n=3)\end{array}$ & & & & & \\
\hline Opaque minerals & & $\begin{array}{l}16.0 \pm 2.7 \\
(n=3)\end{array}$ & & & & & \\
\hline Altered grains & & $\begin{array}{l}5.3 \pm 1.1 \\
(n=3)\end{array}$ & & & & & \\
\hline
\end{tabular}

a Schirrmeister et al. (2008a,b).

b Schwamborn et al. (2002).

c Siegert et al. (2002)

depressions containing circular lakes and 10-15 m deep U-shaped thermo-erosional valleys. These degradation features represent the typical morphology of ice-rich periglacial landscapes in northern Siberian lowlands.

According to Mikulenko (1996) the Chekanovsky Ridge consists of folded Mesozoic slates and sandstones that compose a system of narrow anticlines and broad synclines. The tectonic dislocation continues to the north below the Lena Delta as a system of small grabens and horsts.

The islands of the third Lena Delta terrace are composed of Early to Middle Weichselian fluvial sands and alluvial peaty layers, which are covered by Ice Complex sequences (Fig. 5). In places, Holocene peaty cryosols form the uppermost horizon. The general stratigraphy is similar to the sequences found at Cape Mamontov Klyk 200-300 km to the west. Such sequences are well exposed along the $150 \mathrm{~km}$ long Olenyekskaya Channel and its tributaries in the western Lena Delta (Fig. 2). Three Ice Complex sections typical for the western Lena Delta are presented here from the Khardang Sise, Ebe Basyn Sise (Nagym site), and Kurungnakh Sise (Buor Khaya site) islands.

The general stratigraphical successions as well as the visible structures are comparable for these sections. The Ice Complex cryostructure is characterized by ice bands several centimetres thick and lens-like reticulated ice veins in mineral-rich layers. Vertically laminated ice wedges are 3-5 m wide and $15-20 \mathrm{~m}$ high, contain numerous millimetre-scale gas bubbles, and have symmetrical shoulders merging with ice bands in the surrounding sediments. Such ice wedge features, together with the cryostructure characteristics of segregated ice, reflect the syngenetic formation of ice wedges and permafrost deposits (Popov, 1967; 


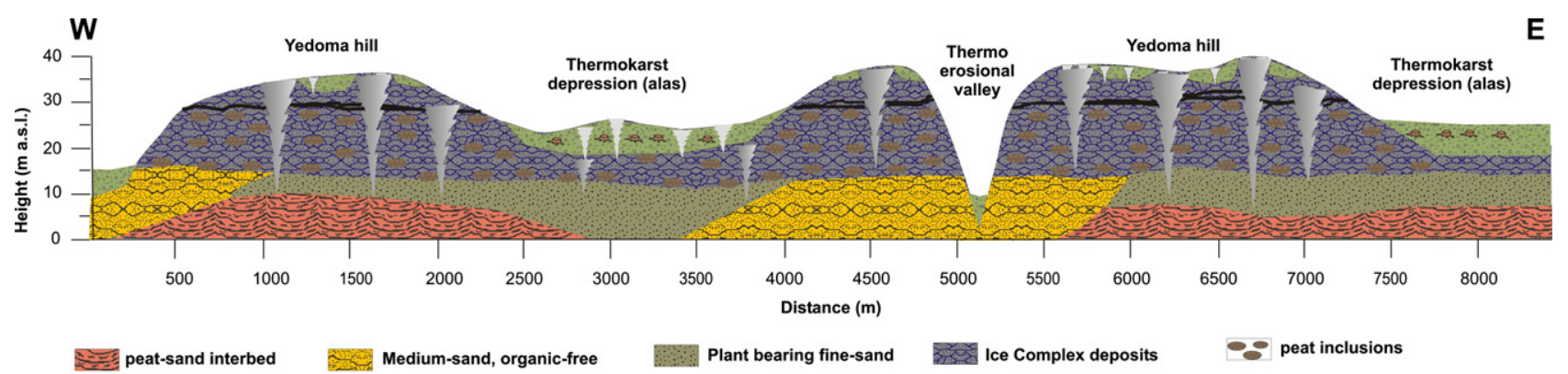

Holocene boggy deposits, wood

$\nabla 7$ ice wedges of different generations

Fig. 5. Generalized cross-section of exposures along the Olenyekskaya Channel (Kurungnakh Sise Island).

Washburn, 1979; Melnikov and Spesivtsev, 2000). Sediment sequences mostly exposed in numerous thermokarst mounds (baydzherakhs) consist of buried cryosols with peat horizons, and additional sand and peat lenses.

The cryolithological properties from these three sites reflect the variety and inhomogeneity in the composition of Ice Complex sequences (Fig. 6). Though mostly ice-saturated or supersaturated, the gravimetric ice content of individual samples varies between 25 and $200 \mathrm{wt} \%$, with an exceptional high ice content of $370 \mathrm{wt} \%$ in one sample. Very high gravimetric ice contents are usually caused by occurrences of ice-rich peat inclusions or ice bands. The lesssorted grain size distributions are dominated by sand fractions. The mean grain size values at the Khardang Sise, Ebe Basyn Sise (Nagym), and Kurungnakh Sise (Buor Khaya) sites in the Lena Delta range between $40-240 \mu \mathrm{m}, 90-390 \mu \mathrm{m}$, and 35-175 $\mu \mathrm{m}$, respectively (Fig. 6). The sorting varies by about $1-3$ degree in separate sections as well as between the different sites, reflecting frequently changing accumulation conditions. Slight differences of mass-

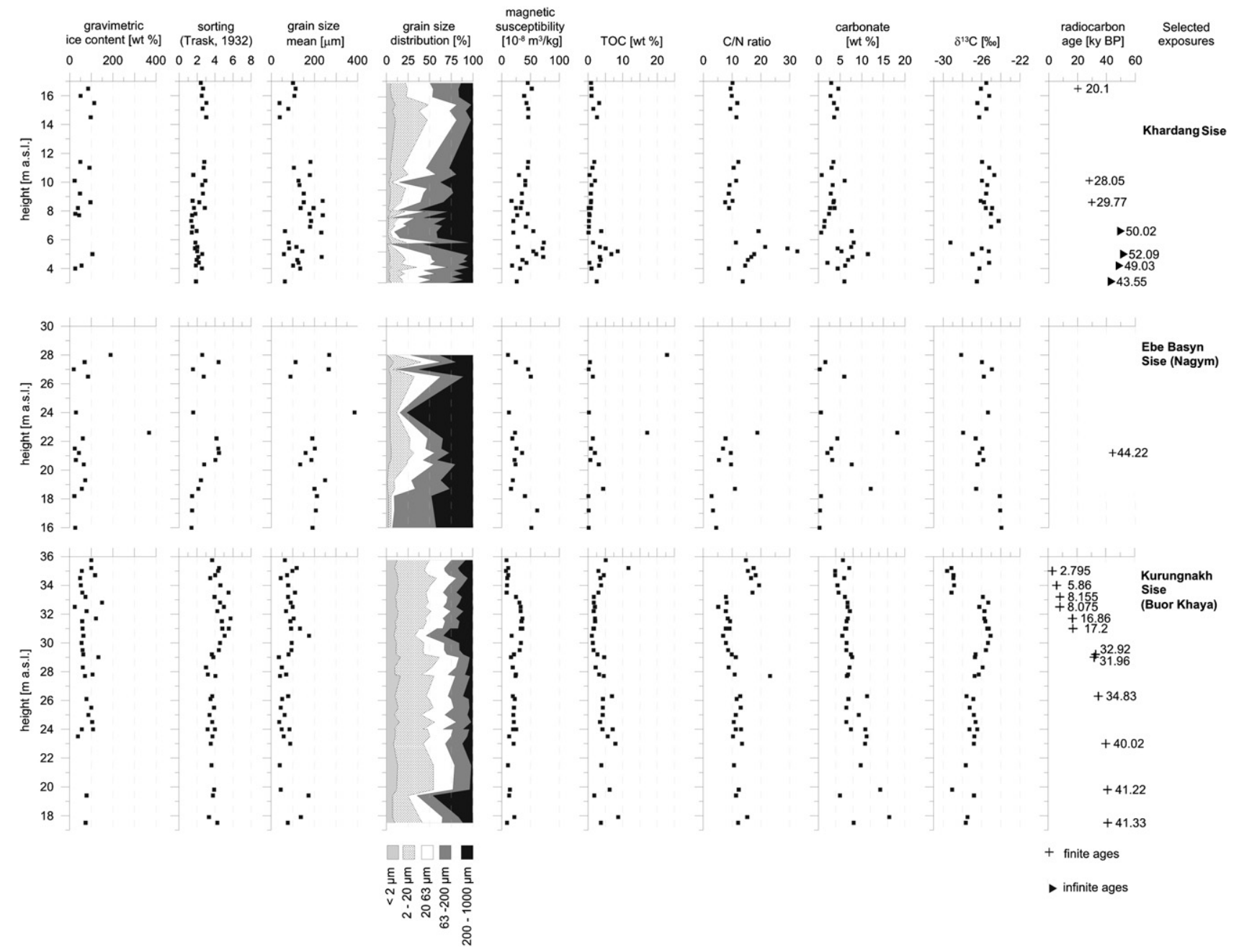

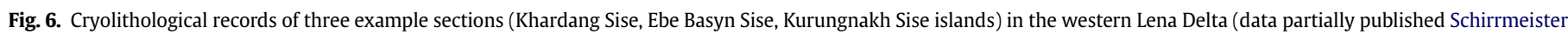
et al., 2003b and Wetterich et al., 2008). 
specific magnetic susceptibility among the different sites are probably related to different local sediment sources. Variations in magnetic susceptibility within the separate profiles by several tens of SI units are probably caused by buried cryosol occurrences. The TOC content varies between $0.1-8.6,0.1-22.8$, and $1.1-11.7 \mathrm{wt} \%$, respectively, within the abovementioned sequences. The $\mathrm{C} / \mathrm{N}$ ratios also exhibit a broad range of 7.6-32.7, 2.9-18.8, and 5.2-23.2, respectively, reflecting variable degrees of organic matter decomposition. Most of the analyzed Ice Complex samples are rich in carbonates. The changing character of organic carbon is also evident by variations in $\delta^{13} \mathrm{C}$ values between -29.1 to $-24.2 \%$, -28.1 to -24.0 and -29.5 to $-25.1 \%$, respectively. Such gradients of about 3.5 to $4 \%$ in $\delta^{13} \mathrm{C}$ are caused by changes in vegetation composition. Aquatic plants prevailing in low-centre polygonal ponds result in less negative values, whereas mosses in peat layers and grass, herb, and shrub communities result in more negative values.

The oldest radiocarbon dates of the Lena Delta Ice Complex sequences are infinite ( $>52$ ka BP; Schirrmeister et al., 2003b). However, the maximum age is limited by the age of the underlying sandy horizon, which has been dated to 60-90 ka by infrared stimulated luminescence dating (Krbetschek et al., 2002; Schwamborn et al., 2002) and $90-110 \mathrm{ka}$ by ${ }^{230} \mathrm{Th} / \mathrm{U}$ dating of peat horizons therein (Schirrmeister et al., 2003b). From Kurungnakh Sise Island, a continuous accumulation of the Ice Complex is recorded during the Middle Weichselian interstadial period between about 50 and $30 \mathrm{ka} \mathrm{BP}$ (Wetterich et al., 2008). Later, the age succession there was interrupted twice. A gap exists between approximately 32 and $17 \mathrm{ka} \mathrm{BP}$, followed by a layer dated to about $17 \mathrm{ka} \mathrm{BP}$, and a second gap between 17 and $8 \mathrm{ka} \mathrm{BP}$ (Wetterich et al., 2008).

The heavy mineral composition is characterized by high content of garnet, epidote, amphibole, and opaque minerals. In addition, zoisite and apatite occur. Zircon, corundum, tourmaline, and pyroxenes were found only in accessory amounts. The heavy mineral association of the Ice Complex deposits in the western Lena Delta is similar to that of sediments sampled in small brooks coming from the Chekanovsky Ridge (Schwamborn et al., 2002). This strongly indicates that the nearby mountain ridge is the local sediment source for these Ice Complex deposits. In contrast, the heavy mineral composition of sandy sediments underlying the Ice Complex deposits is similar to that of the modern Lena River sand composition (Schwamborn et al., 2002).

\subsection{Bykovsky Peninsula and Muostakh Island (Eastern Laptev Sea)}

The Bykovsky Peninsula and Muostakh Island are located about $15 \mathrm{~km}$ apart from each other in the eastern Laptev Sea. They are remnants of an accumulation plain in front of the Kharaulakh Ridge. The low hill range (up to $500 \mathrm{~m}$ asl) consists mainly of permocarboniferous sandstones and slates characterized by strong dissection due to tectonic activity during the Cenozoic. Neotectonic activity in the wider region is proven by various seismic studies (Grigoriev et al., 1996; Drachev et al., 1998; Imaev et al., 2000; Franke et al., 2000).

Muostakh Island is a slender island stretching about $10 \mathrm{~km}$ in the NW-SE direction and less than $750 \mathrm{~m}$ in the NE-SW direction. In its north-east continuation, the Bykovsky Peninsula (Mamontovy Khayata site) is attached to the mainland and geomorphologically shaped by Yedoma elevations (47\%), thermokarst depressions (46\%), and thermo-erosional valleys (6\%) (Grosse et al., 2005). Several exposures along the east coasts of both sites were studied within the framework of Russian-German expeditions in 1998, 1999, 2000, and 2002 (Table 1).

At both sites, Ice Complex sequences between sea level and 20-50 $\mathrm{m}$ asl have been exposed by rapid coastal erosion (Fig. 2). These sequences mostly consist of ice-rich to ice-supersaturated sediments. The ground ice occurs as large syngenetic ice wedges (up to $5 \mathrm{~m}$ wide and up to $40-50 \mathrm{~m}$ deep), and segregated ice, which forms horizontal to subhorizontal ice bands (SOM 1 D), small ice lenses, and dispersed ice cement. The deposits are often organicrich and contain buried cryosols and peat horizons. The Mamontovy Khayata exposure on Bykovsky Peninsula has been the subject of very comprehensive studies in the past (Tomirdiaro et al., 1984; Kunitsky, 1989; Slagoda, 1993; Fukuda, 1994; Nagaoka, 1994; Nagaoka et al., 1995; and all studies from Russian-German expeditions cited in Table 1), making it an outstanding reference section for Late Quaternary paleoenvironmental evolution in North Siberia (Fig. 7). The sequences on Muostakh Island were studied already by Solomatin (1974) and Ivanov and Katasonova (1978). Offshore permafrost cores acquired close to the erosional bluff of Mamontovy Khayata by Russian drill campaigns in the 1980's indicate that the Ice Complex reaches ca. $10 \mathrm{~m}$ below current sea level and is underlain by sandy to gravelly deposits interpreted as Pliocene-Early Pleistocene fluvial deposits (Kunitsky, 1989; Slagoda, 2004). The Yedoma hills are intersected by thermokarst depressions filled with Late Glacial to Holocene lacustrine, proluvial, alluvial, and boggy deposits. Finally, on top of the Ice Complex formation Holocene deposits have accumulated in small initial thaw ponds and polygonal ponds.

The Ice Complex section of Mamontovy Khayata contains Early Weichselian alluvial sandy deposits in its lower part, Middle Weichselian peat horizons and peaty buried cryosols in its middle part, and Late Weichselian proluvial deposits in its upper part. According to grain size analyzes, the poorly to very-poorly sorted sediment consists predominantly of silt and fine to middle-grained sand (Fig. 8). The mean grain size values vary between 16 and

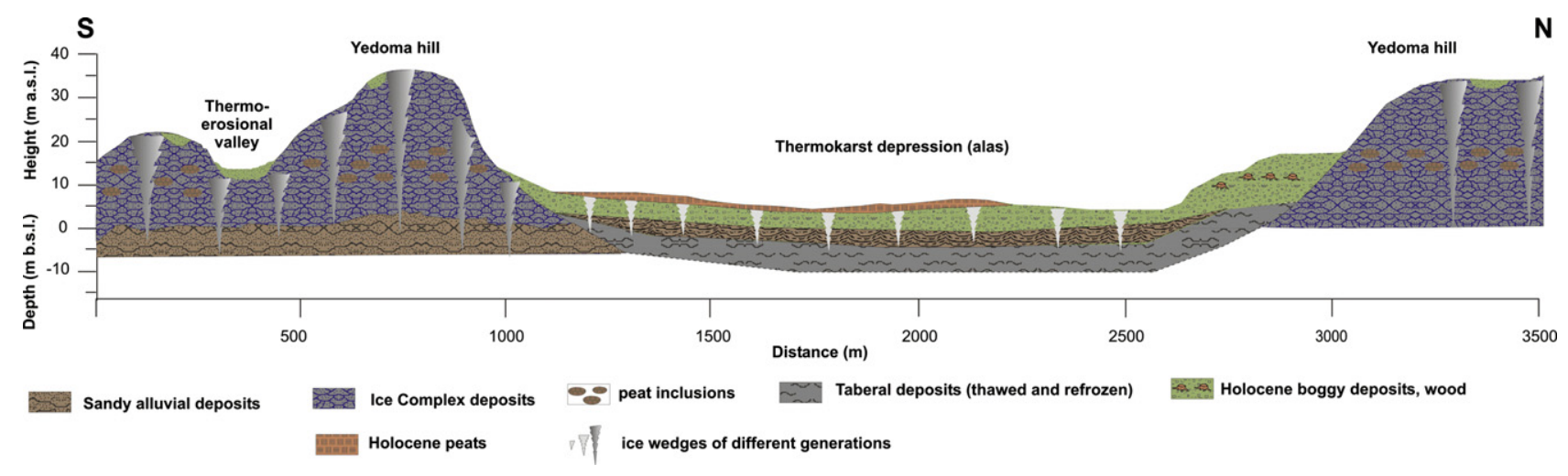

Fig. 7. Generalised stratigraphic cross-section of the Mamontovy Khayata site, east coast of Bykovsky Peninsula. 


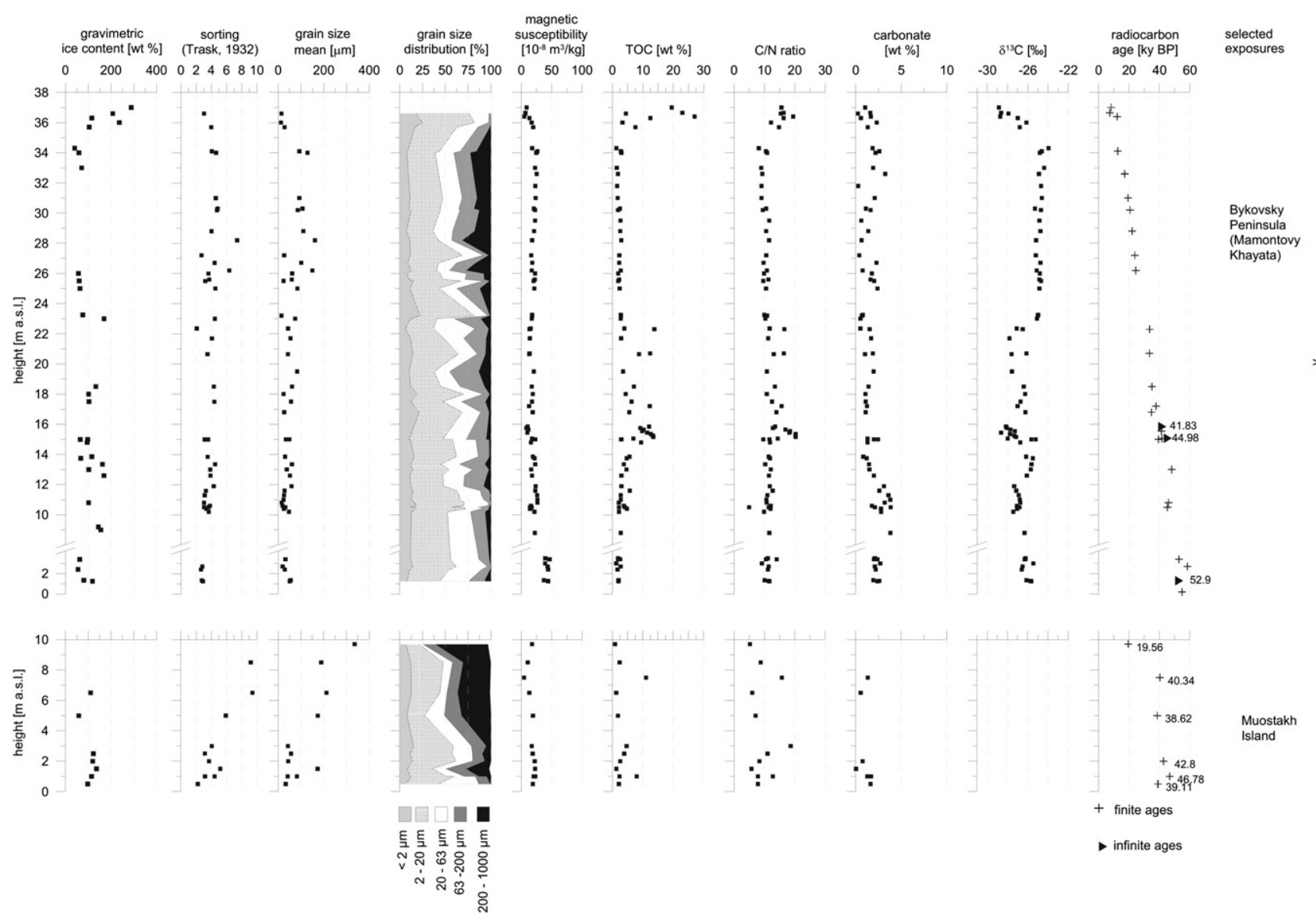

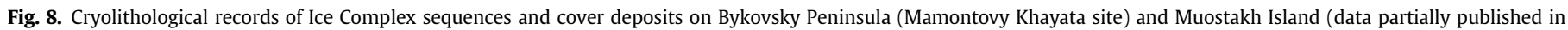
Schirrmeister et al., 2002a).

$161 \mu \mathrm{m}$. Variations in the magnetic susceptibility and grain size distribution reflect most likely a polygenetic formation of these sequences. Carbonate contents between 0.2 and $4.8 \mathrm{wt} \%$ vary throughout the entire sequence. Higher carbonate contents are related to large amounts of freshwater ostracods and molluscs, which inhabited small polygonal ponds (Wetterich et al., 2005). Low accumulation rates but stronger decomposition of organic matter under dry, predominantly aerobic conditions characterize the lower part of the Ice Complex sequence. Greater variations in biogeochemical parameters are typical for the middle part. High TOC values associated with high $\mathrm{C} / \mathrm{N}$ ratios and low $\delta^{13} \mathrm{C}$ values reflect presence of less-decomposed organic matter, possibly due to moist and anaerobic conditions during sediment accumulation. Small and less variable organic carbon contents indicate stable conditions with reduced biological activity in the upper part. Low $\mathrm{C} / \mathrm{N}$ ratios and high $\delta^{13} \mathrm{C}$ values reflect relatively dry, aerobic conditions. Finally, the Holocene cover on top of the Ice Complex sequence is characterized by higher TOC and $\mathrm{C} / \mathrm{N}$ ratios and lower $\delta^{13} \mathrm{C}$ values reflecting the environmental amelioration during the Holocene thermal optimum.

The cryolithological records from the Ice Complex exposure on adjacent Muostakh Island (Fig. 8) are comparable to the Middle and Late Weichselian segments of the Mamontovy Khayata sequence.

The heavy mineral association of the Mamontovy Khayata Ice Complex is dominated by pyroxenes, ilmenite, amphiboles, and epidote (Table 3), which is rather different from the sites presented above, but is similar to the heavy mineral association of surface debris sampled in the hinterland of Bykovsky Peninsula in the Kharaulakh Range (Siegert et al., 2002). This indicates that the major sediment source for the Mamontovy Khayata Ice Complex sequence is this low mountain range. However, the composition within the entire sequence is not uniform but changes by several grain percentages between single layers, reflecting varying transport and accumulation processes during the Ice Complex formation.

\subsection{Stolbovoy, Bel'kovsky, Kotel'ny, and Maly Lyakhovsky Islands (New Siberian Archipelago)}

Paleoenvironmental data from the northern New Siberian Islands are extremely rare. Makeyev et al. (2003) presented some geochronological and pollen datasets from Kotel'ny Island indicating that this area was not glaciated during the Late Quaternary. Five Ice Complex exposures were studied during a joint Russian-German ship expedition to the New Siberian Archipelago in 2002 (Tables 1 and 3; Schirrmeister et al., 2003a) (Fig. 1). This study area belongs to the New Siberian-Chukchi Fold Belt, which is the northernmost part of the Verkhoyansk-Kolymsk Fault Region located on the western margin of the North American Plate (Drachev et al., 1998). The bedrock consists of strongly folded Paleozoic sediments (Lopatin, 1998). The landscape is are largely dominated by step-like cryoplanation terraces with several levels extending from hills with exposed bedrock at 100-200 m elevation to near sea level. The lowermost terraces at $10-30 \mathrm{~m}$ asl are often covered by Ice Complex deposits (Fig. 9). Their surface relief is shaped by thermokarst depressions and thermo-erosional valleys with steep slopes, wide flat bottoms, and shallow brooks as well as by frequent, numerous thermokarst mounds on slopes (Fig. 2). 


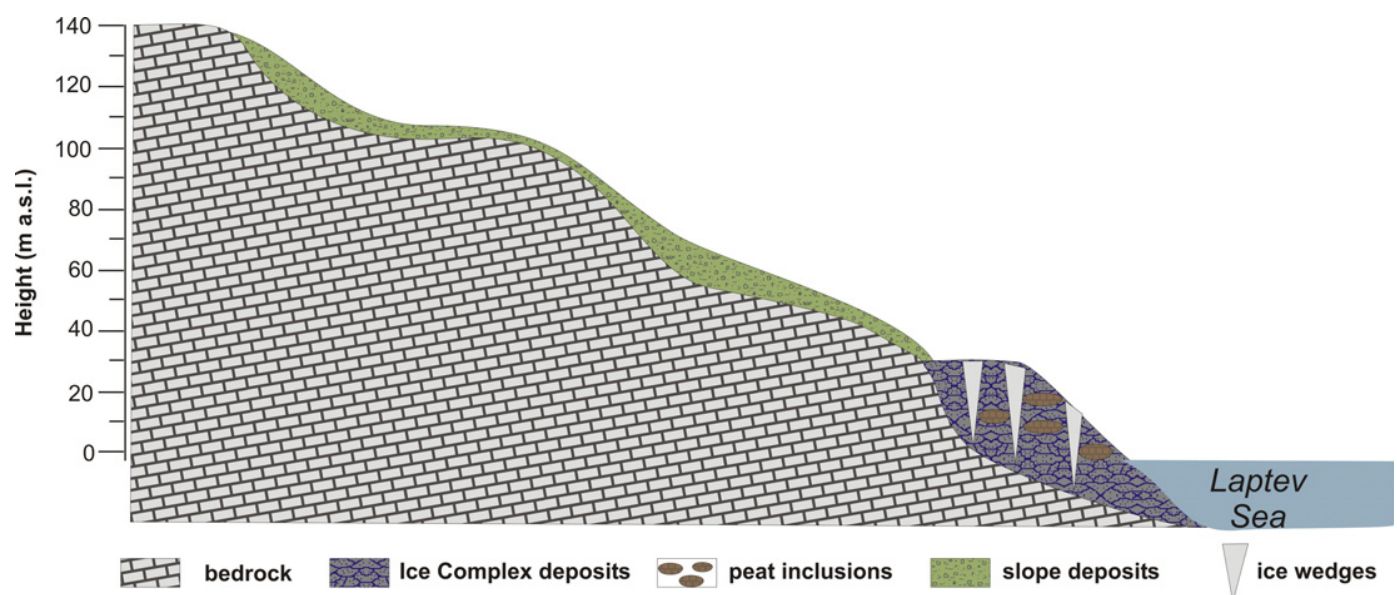

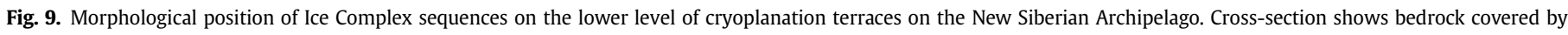
slope deposits.

Because of logistical and time constraints, only one-day trips could be made to each site during the 2002 expedition. Therefore, several-meter-thick profiles were sampled and analyzed only exemplarily. Nevertheless, it is possible to summarise the cryolithological findings and compare these with results from other exposures that were studied more intensively. To the best of the authors' knowledge, these sequences of the New Siberian Archipelago represent the northernmost Siberian Ice Complex sequences remaining today.
Buried composite ice-ground wedges about $1 \mathrm{~m}$ wide with rounded (thawed) head parts were repeatedly found in the lower part of sequences close to sea level. They are composed of vertically alternating mineral ( $7-10 \mathrm{~mm}$ thick) and ice $(5-7 \mathrm{~mm}$ thick) veins. Typical grey ice wedges, several meters wide, vertically laminated, and containing large number of gas bubbles were observed in the upper part of the Ice Complex sequences. The frozen sediment was predominantly composed of greyish fine-grained material containing abundant grass roots and some

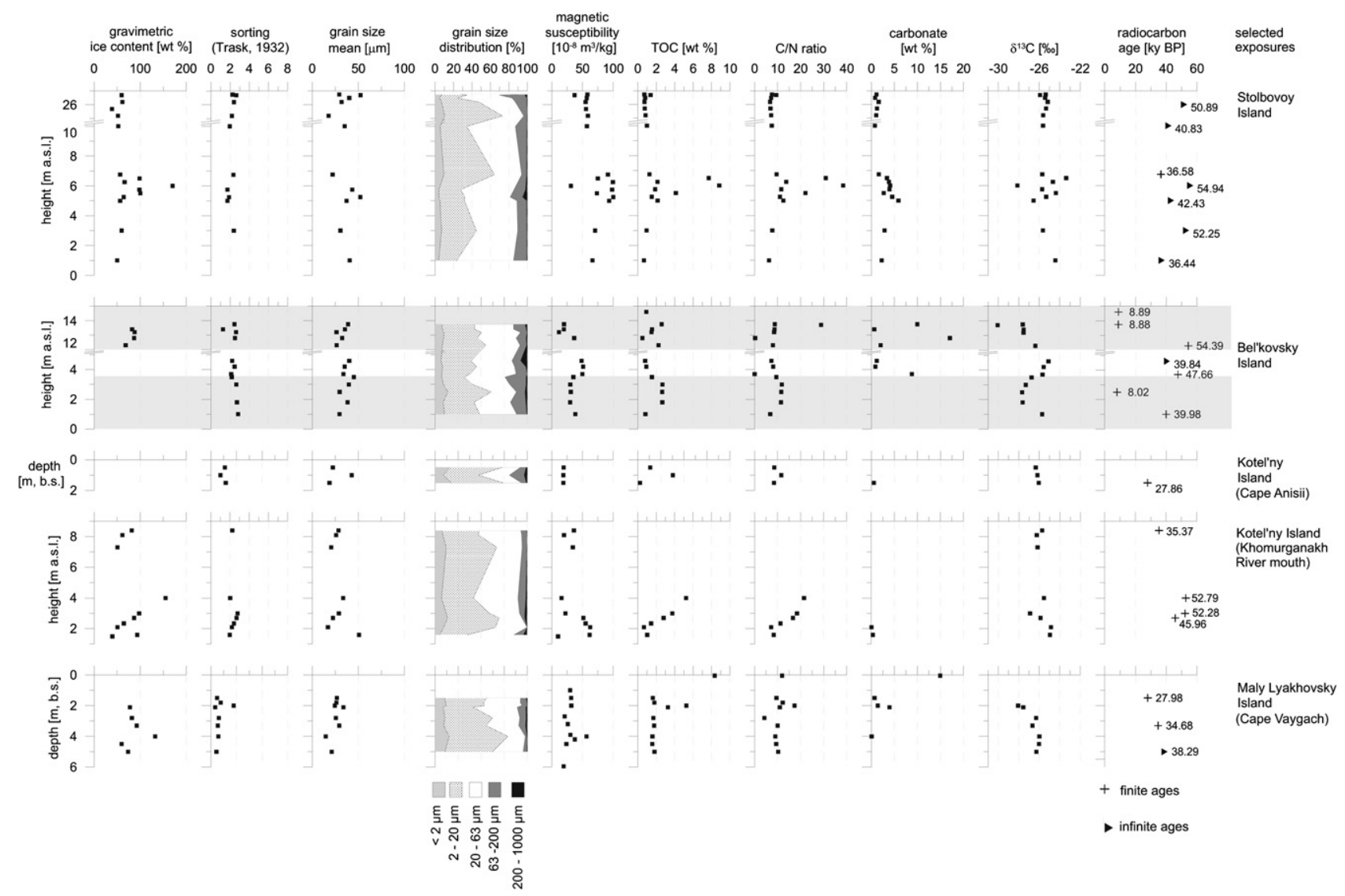

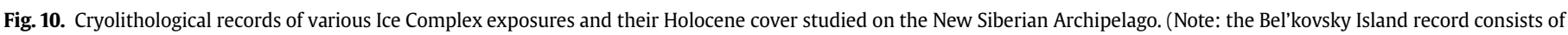
three separate profiles which were only combined by height but not stratigraphically). 
peat inclusions. In the lower part of the section at the Khomurganakh River mouth (SW Kotel'ny Island) gravels and rounded pebbles occurred. At two sites (Stolbovoy and Bel'kovsky Island) typical $1-2 \mathrm{~m}$ thick peaty horizons were studied. In general, the observed banded cryostructures point to syncryogenic accumulation, which is evident by ice bands continuing as shoulders of ice wedges. The deposits are mostly ice-rich or icesupersaturated with a gravimetric ice content ranging from 30 to $170 \mathrm{wt} \%$.

All analyzed Ice Complex samples from these sites (Fig. 10) are characterized by a relatively uniform low grain size with mean values between $20-40 \mu \mathrm{m}$ and a low sorting degree. The grain size composition is dominated by silt. Only a small part $(<15 \%)$ was classified as fine to middle-grained sand. The mass-specific magnetic susceptibility differs between various sites as well as within longer profiles. The highest values were measured in Ice Complex samples from Stolbovoy Island (about $100 \mathrm{SI}$ ), indicating a different sediment source for these deposits. The TOC content varies between 0.5 and $8.8 \mathrm{wt} \%$ depending on the occurrence of peat inclusions and buried peaty cryosols. Horizons with higher organic carbon content are also characterized by higher $\mathrm{C} / \mathrm{N}$ ratios, reflecting less decomposition of organic matter. The Ice Complex deposits from five exposures studied on the northern New Siberian Archipelago were radiocarbon-dated to between older than 55 ka BP to 28 ka BP (Table 2). The youngest deposits were found either on top of coastal exposures (e.g. Stolbovoy Island) or in the top parts of thermokarst mounds (e.g. Kotel'ny Island, Cape Ansii, or Maly Lyakhovsky Island, Cape Vaygach). There are no Ice Complex formations younger than $28 \mathrm{ka}$ BP on the New Siberian Islands. In places, Ice Complex deposits in the studied sections were covered by Holocene deposits (e.g. Bel'kovsky Island).

The heavy mineral fraction from Stolbovoy Island Ice Complex samples is dominated by micas and chlorite followed by amphibole and epidote. At Bel'kovsky Island the heavy mineral spectra are dominated by amphibole, epidote, muscovite, and pyroxene. Ice Complex samples from Kotel'ny Island (Cape Anisii) exhibit yet another heavy mineral composition. The mineralogical signatures of the abovementioned sequences clearly differ from those of the western and eastern Laptev Sea coasts and the Lena Delta (Table 3). Though bedrock debris for mineralogical comparison was not found, a close genetic relationship of the Ice Complex deposits to the nearby Jurassic and Cretaceous (Stolbovoy), Devonian (Bel'kovsky), or Ordovician (Kotel'ny) bedrock hills, and thus to local sediment sources, can be assumed (Table 4).

\subsection{Bol'shoy Lyakhovsky Island (New Siberian Archipelago)}

Permafrost sequences on the south coast of the southernmost island of the New Siberian Archipelago were investigated in detail by a Russian-German expedition to the Zimov'e River mouth on Bol'shoy Lyakhovsky Island in 1999 and 2007 (Fig. 1). Based on this fieldwork, several paleoenvironmental papers have already been published (Table 1). Ice Complex deposits of Bol'shoy Lyakhovsky Island were described and initially studied in the 19th century (Bunge, 1885; von Toll, 1895). Later on, detailed geocryological studies were carried out by Romanovskii (1958a,b,c), Nagaoka et al. (1995), Arkhangelov et al. (1996), and Kunitsky (1998).

The island's surface consists of gradually sloping terrain intersected by rivers and thermo-erosional valleys. The latter appear as either wide, U-shaped, and often meandering valleys with a flat bottom (altitude: $10-20 \mathrm{~m}$ asl), or as deep (5-10 m), short (50-100 m) and straight V-shaped gullies. Yedoma hills of about $40 \mathrm{~m}$ high alternate with large thermokarst depressions with gentle slopes and flat bottoms (diameter: $1-2 \mathrm{~km}$, floor elevation: 12-15 $\mathrm{m}$ asl). Most basins on Bol'shoy Lyakhovsky Island contain no lakes today. Exposures of mostly cretaceous granitic bedrock exist at the hills of Kigilyakh, Khaptagay Tas, and Emii Tas with elevations up to $200 \mathrm{~m}$ asl. They are surrounded by cryoplanation terraces (Kunitsky, 1998; Kunitsky et al., 2002). Thermal abrasion has resulted in the coastal erosion of Ice Complex elevations on the south coast of Bolshoy Lyakhovsky (Dmitry Laptev Strait) and the formation of thermo-erosional cirques. These cirques are formed by rapidly retreating horseshoe-shaped bluffs of ice-rich deposits on upper levels (ca. 10-35 $\mathrm{m}$ asl), and 50-100 $\mathrm{m}$ wide terraces at lower levels (ca. $10 \mathrm{~m}$ a.s.1.).

The Middle Weichselian Ice Complex deposits on the south coast of Bol'shoy Lyakhovsky Island are underlain by Early Weichselian, Eemian, and Pre-Eemian deposits in several locations (Fig. 11) well exposed on the coast west and east of the Zimov'e River mouth (Schirrmeister et al., 2001; Andreev et al., 2004, 2009). In places, a Holocene cover was found on top of the Ice Complex exposures.

Ice Complex deposits are exposed in thermokarst mounds (2-5 $\mathrm{m}$ high) on the thermo-terrace as well as in the horseshoeshaped steep bluffs up to $25 \mathrm{~m}$ high (Fig. 2). These bluffs contain ice wedges up to $6 \mathrm{~m}$ wide and up to $25 \mathrm{~m}$ high and similarly-sized columns of fine-grained silty sediments with peat inclusions and buried cryosol horizons. High segregated ground ice content is characteristic for these deposits (gravimetric ice content 40-160 wt\%; Fig. 12). The predominant cryostructures are alternately banded and lens-like reticulated (SOM $1 \mathrm{G}, \mathrm{H}$ ).

Table 4

Hinterland geology and geomorphology of the New Siberian Archipelago Ice Complex study sites.

\begin{tabular}{|c|c|c|c|}
\hline Study area/site & $\begin{array}{l}\text { Basement lithology } \\
\text { (Lopatin, 1998) }\end{array}$ & $\begin{array}{l}\text { Macroscale } \\
\text { geomorphology }\end{array}$ & $\begin{array}{l}\text { Mesoscale } \\
\text { geomorphology }\end{array}$ \\
\hline Stolbovoy Island & $\begin{array}{l}\text { Jurassic and } \\
\text { Cretaceous } \\
\text { sediment rocks }\end{array}$ & $\begin{array}{l}\text { Mountain ridges } \\
(100-220 \mathrm{~m} \text { asl })\end{array}$ & Cryoplanation terraces \\
\hline $\begin{array}{l}\text { Bel'kovsky Island/ } \\
\text { Cape Skalisty }\end{array}$ & $\begin{array}{l}\text { Devonian } \\
\text { sediment rocks, } \\
\text { NW-SE faults }\end{array}$ & Rocky cliffs & $\begin{array}{l}\text { Cryoplanation terraces } \\
(80,60-40,25 \mathrm{~m} \text { asl), } \\
\text { thermokarst depression, } \\
\text { thermo-erosional valleys }\end{array}$ \\
\hline Kotel'ny Island, N/ & Ordovician & Grebyenochnaya & Cryoplanation terraces \\
\hline Cape Anisii & limestone & hill (92.6 m asl) & between 100 and $10 \mathrm{~m}$ asl \\
\hline $\begin{array}{l}\text { Kotel'ny Island, SW/ } \\
\text { Khomurganakh River } \\
\text { mouth }\end{array}$ & & $\begin{array}{l}\text { Sogurum Tas hill } \\
(172 \mathrm{~m} \text { asl })\end{array}$ & Cryoplanation terraces \\
\hline $\begin{array}{l}\text { Maly Lyakhovsky Island/ } \\
\text { Cape Vaygach }\end{array}$ & $\begin{array}{l}\text { Upper Jurassic and } \\
\text { Lower Cretaceous } \\
\text { sediment rocks }\end{array}$ & & $\begin{array}{l}\text { Step-like terraces }(30,25 \text {, } \\
20 \mathrm{~m} \text { asl thermokarst lakes, } \\
\text { thermo-erosional valleys }\end{array}$ \\
\hline
\end{tabular}




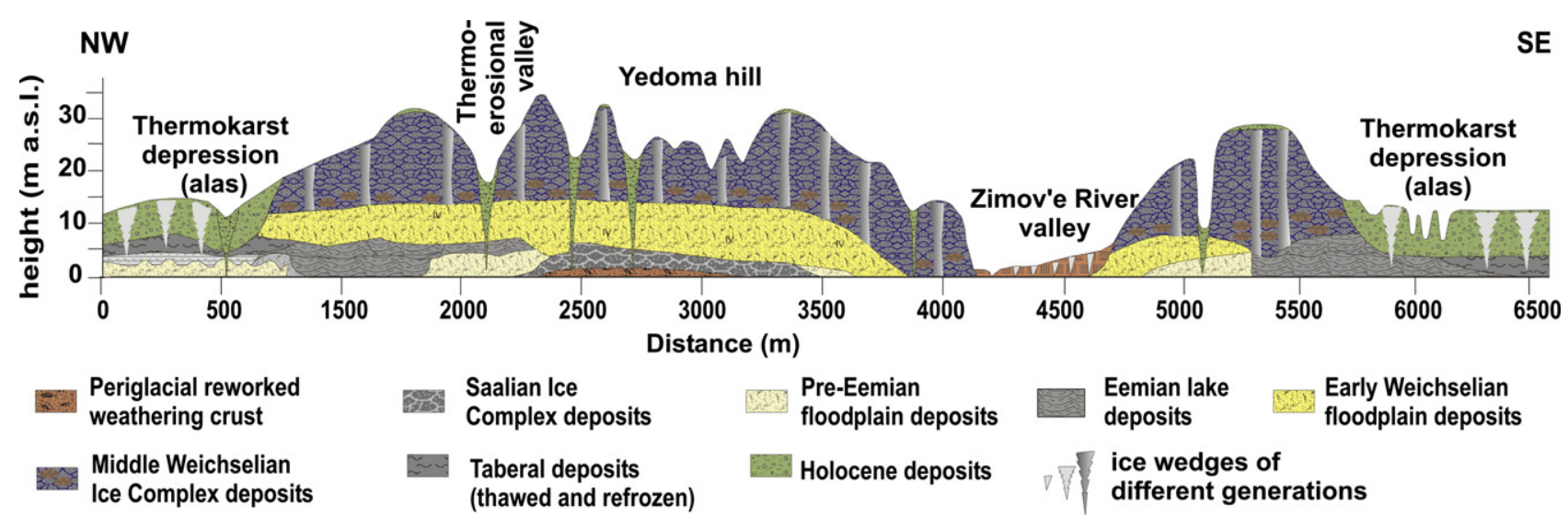

Fig. 11. Generalized stratigraphic cross-section of the south coast of Bol'shoy Lyakhovsky Island at the Zimov'e River mouth (redrawn after Andreev et al., 2004).

Cryolithological characteristics from four combined profiles exposed in various thermo-erosional cirques are summarized in Fig. 12. Similar to the northern islands of the New Siberian Archipelago, but different from sites on the Laptev Sea mainland coast, the grain size is dominated by silt fractions. Changes in massspecific magnetic susceptibility of more than 50 SI within single short subprofiles as well as between several sites, reflect a variable sediment lithology possibly caused by different sedimentary factors (e.g. water runoff, detritus input). The organic carbon preserved in the Ice Complex sediments ranges between about 0.5 and $25 \mathrm{wt} \%$. High amounts were measured in peaty horizons and buried cryosols. The degree of organic matter decomposition is higher $(\mathrm{C} / \mathrm{N}$ ratio about 10$)$ if TOC contents are lower, whereas peaty horizons with high TOC contents are characterized by lower decomposition. Such changes are often related to variations of $\delta^{13} \mathrm{C}$ values reflecting varying degrees of organic matter composition.

Ice Complex deposits on Bol'shoy Lyakhovsky Island were formed during the Middle Weichselian period between about $55 \mathrm{ka}$ and $28 \mathrm{ka}$ BP. No younger Ice Complex deposits were found in the sequences, which in places were discordantly covered by Holocene deposits.

The heavy mineral association is dominated by amphibole and micas, followed by epidote and pyroxene (Table 3 ), probably due to the proximity of several hills exposing granitic bedrock. The composition is clearly different from the heavy mineral composition of Ice Complex deposits from Stolbovoy Island.

\subsection{Cape Svyatoy Nos and the Oyogos Yar coast}

At both sites studied on the mainland coast of the Dmitry Laptev Strait (Fig. 1), the general geomorphological and stratigraphical situation is comparable to that of Bol'shoy Lyakhovsky Island's south coast. A chain of Cretaceous granite domes up to $433 \mathrm{~m}$ asl dominates the landscape of Cape Svyatoy Nos (Lopatin, 1998). Cryoplanation terraces are formed around these elevations at various levels. The lowest terrace at about $30 \mathrm{~m}$ asl is covered by Ice Complex deposits, which are underlain by Middle Pleistocene terrestrial deposits (Nikolskiy et al., 1999; Nikolskiy and Basilyan, 2004; Gilichinsky et al., 2007). The Ice Complex thickness is about $10 \mathrm{~m}$. The width of ice wedges is $2-3 \mathrm{~m}$ and the spacing between ice wedges is $10-12 \mathrm{~m}$. The cryostructure is predominantly ice-banded and lens-like reticulated between ice bands.

Further east, the coast of Oyogos Yar was studied by Russian scientists during recent decades. Ice Complex deposits covering the very gently inclined step-like surface of the Yana-Indigirka Lowland were formerly interpreted as sequences of interlocked lake terraces
(Kayalainen and Kulakov, 1966). In another interpretation, the steplike distribution of this horizon was connected with steps of cryoplanation terraces (Kunitsky, 1996). Gravis (1978) and Konishchev and Kolesnikov (1981) assumed that the Ice Complex of Oyogos Yar was formed within Eemian thermokarst depressions. Tomirdiaro (1970, 1980) assumed an aeolian origin for these deposits. The landscape inland from the Oyogos Yar coast is dominated by large basins, which combine several thermokarst depressions filled with large lakes and separate single Yedoma hills between the basins. Permafrost sequences underlying the Ice Complex likely accumulated during Eemian and Pre-Eemian Middle Pleistocene periods (Wetterich et al., 2009) (Fig. 13).

The lowermost Ice Complex deposits are exposed in thermokarst mounds on thermo-terraces about $10-12 \mathrm{~m}$ asl (SOM $1 \mathrm{~A}$ ), and continue with sequences exposed in steep bluffs up to 25-30 $\mathrm{m}$ asl The mostly grey-brown sandy silt contains small peat lenses $(2 \times 2 \mathrm{~cm}$ in diameter) and large peat inclusions (up to $20 \times 40 \mathrm{~cm}$ in size), which belong to buried cryosols. Twig fragments, grass roots, and fine distributed plant detritus are also common in the mineral matrix. The cryostructure is dominated by $1-10 \mathrm{~mm}$ thick ice bands spaced $5-10 \mathrm{~cm}$ apart, and lens-like reticulated segregated ice between ice bands (SOM $1 \mathrm{C}$ ). The deposits are ice-supersaturated, with gravimetric ice contents from 50 to more than $200 \mathrm{wt} \%$ (Fig. 14). Ice wedges exposed in the steep bluffs are up to $20 \mathrm{~m}$ high, $2-5 \mathrm{~m}$ wide in the lowermost part and 8-10 $\mathrm{m}$ wide in the upper part (Fig. 2).

The cryolithological features of the two studied sequences (Fig. 14) differ in grain size distribution and magnetic susceptibility, probably due to different local sediment source areas and the proximity of the Cape Svyatoy Nos granite domes to the corresponding Ice Complex deposits. In addition, the Ice Complex of Oyogos Yar contains twice as much organic carbon as the Ice Complex at Cape Svyatoy Nos. According to radiocarbon dating these sequences accumulated between about 48 and $34 \mathrm{ka}$ BP (Table 2, Fig. 14).

\section{Facies discussion}

\subsection{Geomorphology}

The widespread of Late Pleistocene Ice Complex formations in periglacial landscapes of northern East Siberia is obvious from modern distribution patterns of typical landscape units related to the ice-rich permafrost deposits and their degradation during the Late Glacial and the Holocene. Basins with thermokarst lakes and thermo-erosional valleys shape the modern lowland relief and 


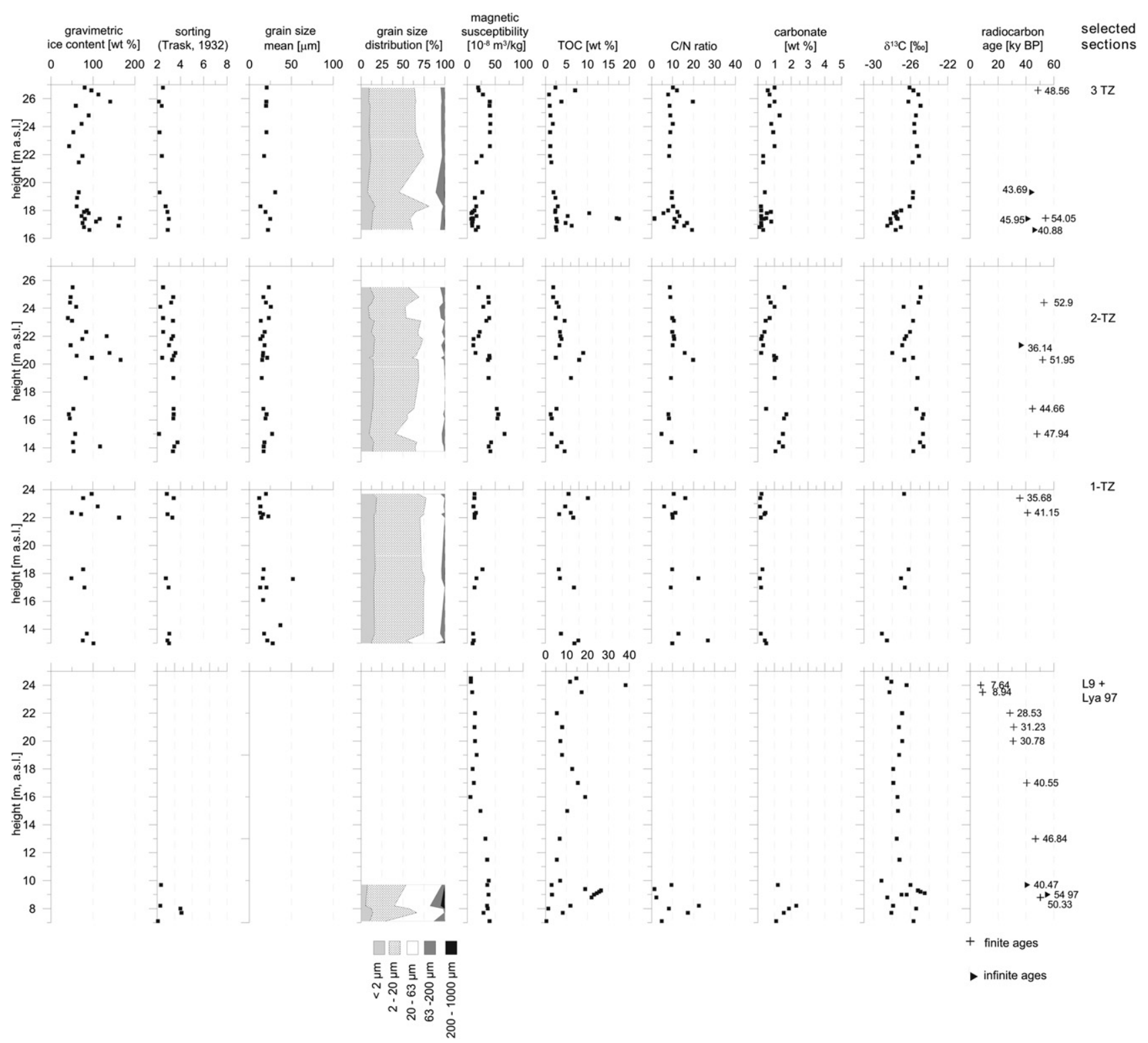

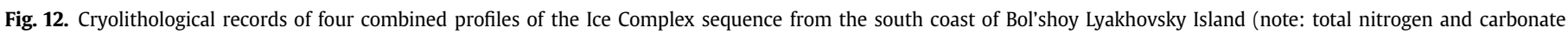
contents were not measured in subprofile Lya 97).

dissect the remnants of Late Pleistocene accumulation plains into Yedoma hills and uplands.

Other indicators pointing to the presence of Ice Complex deposits are thermo-erosional cirques several hundred meters wide and several tens of meters deep on coasts, lake shores, and river banks, exposing numerous thermokarst mounds as well as large ice wedges $2-5 \mathrm{~m}$ wide and $10-40 \mathrm{~m}$ high. The exposed ice wedges, sediment columns and thermokarst mounds are parts of

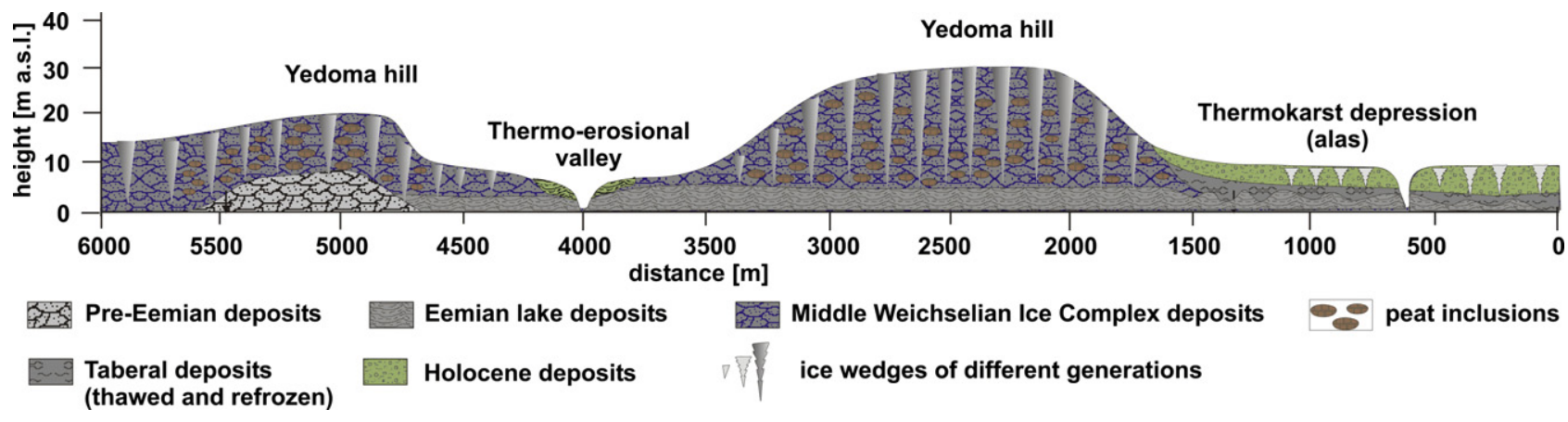

Fig. 13. Generalized stratigraphic cross-section of the permafrost exposure on the Oyogos Yar coast. 


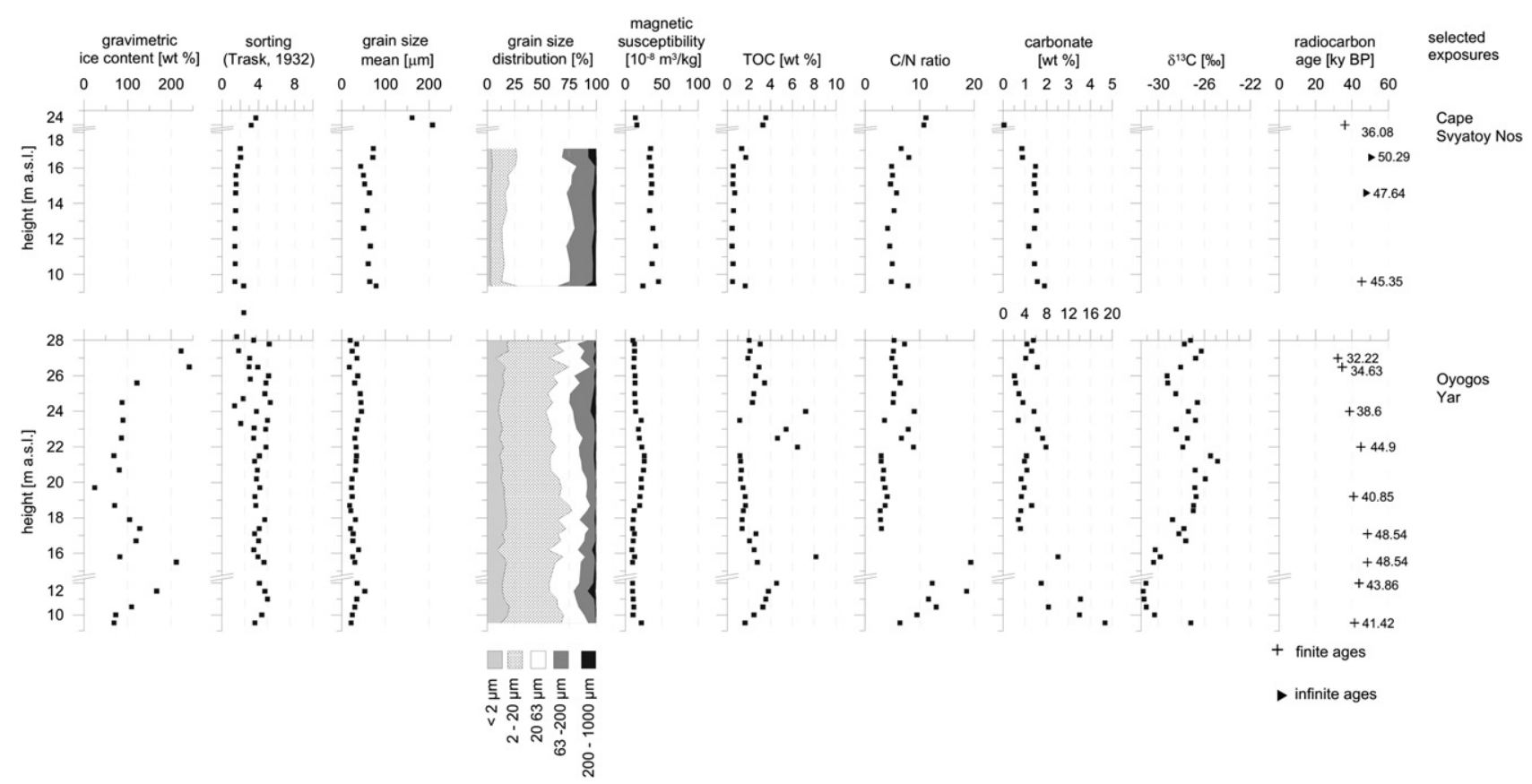

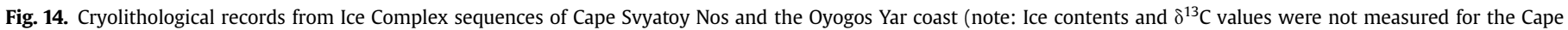
Svyatoy Nos profile).

fossil polygonal ice wedge systems that formed over long time periods.

Three different main geomorphologic situations could be distinguished that characterise the occurrence of Ice Complex formations in the study region. In the western Laptev Sea and in the Lena Delta region their occurrence is strongly connected to the low-elevation coastal mountains of the Pronchishchev, Chekanovsky, and Kharaulakh ridges, which served as the main sediment sources. Heavy mineral studies at various sites prove the dominantly local origin of sediments and their transportation pathways. Gently-inclined foreland accumulation plains covered with widespread ice wedge polygon systems were the original landscape type in which Ice Complex formation occurred during the Late Pleistocene. The second landscape type is related to cryoplanation terraces formed on the slopes of granitic intrusions exposed on hills (100-400 m asl) on Bol'shoy Lyakhovsky and Cape Svyatoy Nos, as well as on slopes of the geologically more complex fault ranges on Bel'kovsky, Stolbovoy, and Kotel'ny Islands. Since the area was not glaciated, these bedrock exposures underwent strong frost weathering in nival landscapes during the Pleistocene and served as sediment sources for the accumulation of Ice Complex deposits. The third type of setting is found in extended lowland areas further away from mountain ranges. Although these distal areas are currently dominated by large and numerous thermokarst basins and lakes, Ice Complex remnants are frequently found in between them indicating their former widespread occurrence. This is e.g. the case for large stretches in the Yana-Indigirka lowland, exemplified by the hinterland of the Oyogos Yar coast.

All these accumulative landscape types were characterized by extensive, relatively flat surfaces with a very low hydrological gradient. The presumably poorly developed drainage system in this Late Pleistocene environment with its low precipitation climate and low hydrological gradients was very likely an important factor for Ice Complex formation. Such less-inclined and relatively stable accumulation plains were a prerequisite for the long-term stable formation of polygon systems with extremely large and densely spaced syngenetic ice wedges.

\subsection{Cryolithology}

The cryostructures in Ice Complex sediments between syngenetic ice wedges are very similar at all the study sites, indicating comparable conditions for syncryogenic incorporation of sediment and soils into the permafrost with ongoing sedimentation. The general sediment structure is dominated by bedded mineral-rich layers alternating with organic-rich buried cryosols; both are intersected by horizontal ice bands (SOM 1). The sediment contains numerous ice lenses in various sizes in a typical net-like reticulated cryostructure. Such cryostructures are the most typical features of sediments formed under poor drainage conditions in periglacial landscapes with a near-surface permafrost table (Dostovalov and Kudryavtsev, 1967). The formation of ice bands indicates that surface conditions and active layer depths were stable for longer periods of time, resulting in ice enrichment near the permafrost table. The frozen sediment sequences are frequently ice-supersaturated, with gravimetric ice contents of $72-114 \mathrm{wt} \%$ on average for various sites (Table 5 ). That corresponds to an absolute ice content of $36-57 \mathrm{wt} \%$ for the sediment part of the Ice Complex. Taking into account that ice wedges account for about $50 \%$ by volume of Ice Complex sequences, the total ground ice content in Ice Complex deposits might range from 65 to $90 \mathrm{Vol} \%$.

Ice Complex deposits at different sites can be considered to be sequences of buried cryosols. These fossil cryosol horizons are characterized by brownish organic-rich patches, peat nests, and numerous single plant remains ranging from well-preserved grass roots to twigs and leaves (SOM $1 \mathrm{E}, \mathrm{F}$ ). Cryoturbated disturbances of $0.5-1 \mathrm{~m}$ vertical extension are very common. The mean organic carbon content is relatively high, but individual horizons within a sequence vary greatly. Whereas mineral-rich horizons have as low as $0.5 \mathrm{wt} \% \mathrm{TOC}$, organic-rich horizons with concentrated patches of organic remains can have up to $27 \mathrm{wt} \%$ TOC. The Ice Complex predominantly formed under subaerial conditions in polygonal patterned periglacial landscapes. The TOC variations are in the same range as in modern Typic Aquiturbels in polygon walls (0.5-3.5 wt\%) and Typic Historthels in polygon centres (1 to $>20 \mathrm{wt} \%$ ) (Kutzbach 
Table 5

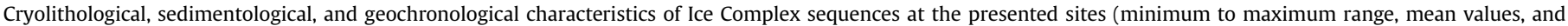
number of samples)

\begin{tabular}{|c|c|c|c|c|c|c|c|c|c|c|}
\hline Site & $\begin{array}{l}\text { Height } \\
{[\mathrm{m} \text { a.s.l] }}\end{array}$ & $\begin{array}{l}\text { Ice } \\
\text { content } \\
\text { [wt\%] }\end{array}$ & $\begin{array}{l}\text { Sorting } \\
\text { (Trask) }\end{array}$ & $\begin{array}{l}\text { Mean } \\
{[\mu \mathrm{m}]}\end{array}$ & $\begin{array}{l}\text { Susceptibility } \\
{\left[10^{-8} \mathrm{~m}^{3} / \mathrm{kg}\right]}\end{array}$ & $\begin{array}{l}\text { TOC } \\
{[w t \%]}\end{array}$ & $\mathrm{C} / \mathrm{N}$ & Carbonate & $\begin{array}{l}\delta^{13} \mathrm{C} \\
{[\%]}\end{array}$ & $\begin{array}{l}{ }^{14} \mathrm{C} \\
{[\mathrm{ky} \text { B.P.] }}\end{array}$ \\
\hline $\begin{array}{l}\text { Cape Mamontov } \\
\text { Klyk }\end{array}$ & $0.5-23.5$ & $\begin{array}{l}47-233 \\
86 \\
(n=35)\end{array}$ & $\begin{array}{l}1.7-6.2 \\
2.6 \\
(n=59)\end{array}$ & $\begin{array}{l}9-115 \\
40 \\
(n=59)\end{array}$ & $\begin{array}{l}15-60 \\
45 \\
(n=60)\end{array}$ & $\begin{array}{l}1.4-8.5 \\
2.8 \\
(n=60)\end{array}$ & $\begin{array}{l}5.4-16.1 \\
15.2 \\
(n=60)\end{array}$ & $\begin{array}{l}0.2-6.0 \\
3.3 \\
(n=62)\end{array}$ & $\begin{array}{l}-28.53 \text { to }-25.04 \\
-26.02 \\
(n=58)\end{array}$ & $\begin{array}{l}27.2-15.0 \\
(n=14)\end{array}$ \\
\hline $\begin{array}{l}\text { Khardang Sise } \\
\text { Island }\end{array}$ & $3.0-17.0$ & $\begin{array}{l}23-114 \\
63 \\
(n=15)\end{array}$ & $\begin{array}{l}1.4-3.0 \\
2.2 \\
(n=33)\end{array}$ & $\begin{array}{l}38-240 \\
135 \\
(n=33)\end{array}$ & $\begin{array}{l}17-73 \\
40 \\
(n=33)\end{array}$ & $\begin{array}{l}0.1-8.6 \\
1.9 \\
(n=33)\end{array}$ & $\begin{array}{l}7.6-32.7 \\
13.6 \\
(n=33)\end{array}$ & $\begin{array}{l}0.6-11.4 \\
4.2 \\
(n=33)\end{array}$ & No data & $\begin{array}{l}>52-20.1 \\
(n=7)\end{array}$ \\
\hline $\begin{array}{l}\text { Ebe Basyn Sise } \\
\text { Island }\end{array}$ & $16-28$ & $\begin{array}{l}19-368 \\
77 \\
(n=15)\end{array}$ & $\begin{array}{l}1.4-4.4 \\
2.8 \\
(n=15)\end{array}$ & $\begin{array}{l}88-386 \\
203 \\
(n=15)\end{array}$ & $\begin{array}{l}11-62 \\
30 \\
(n=16)\end{array}$ & $\begin{array}{l}0.1-22.8 \\
3.6 \\
(n=15)\end{array}$ & $\begin{array}{l}2.9-18.8 \\
8.0 \\
(n=10)\end{array}$ & $\begin{array}{l}0.2-18.2 \\
4.3 \\
(n=14)\end{array}$ & $\begin{array}{l}-28.13 \text { to }-23.95 \\
-25.86 \\
(n=15)\end{array}$ & $\begin{array}{l}44.22 \\
(n=1)\end{array}$ \\
\hline $\begin{array}{l}\text { Kurungnakh Sise } \\
\text { Island }\end{array}$ & $17.5-32.1$ & $\begin{array}{l}38-133 \\
79 \\
(n=21)\end{array}$ & $\begin{array}{l}3.0-5.7 \\
4.0 \\
(n=27)\end{array}$ & $\begin{array}{l}36-175 \\
79 \\
(n=27)\end{array}$ & $\begin{array}{l}9-36 \\
23 \\
(n=27)\end{array}$ & $\begin{array}{l}1.1-8.7 \\
3.8 \\
(n=27)\end{array}$ & $\begin{array}{l}6.9-23.2 \\
11.1 \\
(n=27)\end{array}$ & $\begin{array}{l}1.2-15.5 \\
5.3 \\
(n=27)\end{array}$ & $\begin{array}{l}-29.07 \text { to }-25.07 \\
-26.55 \\
(n=27)\end{array}$ & $\begin{array}{l}41.44-16.86 \\
(n=8)\end{array}$ \\
\hline $\begin{array}{l}\text { Bykovsky P. } \\
\text { (Mamontovy } \\
\text { Khayata) }\end{array}$ & $0-37$ & $\begin{array}{l}40-236 \\
107 \\
(n=40)\end{array}$ & $\begin{array}{l}2.0-7.4 \\
3.8 \\
(n=41)\end{array}$ & $\begin{array}{l}12-161 \\
53 \\
(n=48)\end{array}$ & $\begin{array}{l}5-46 \\
21 \\
(n=108)\end{array}$ & $\begin{array}{l}1.3-27.0 \\
4.8 \\
(n=112)\end{array}$ & $\begin{array}{l}4.9-20.3 \\
11.9 \\
(n=112)\end{array}$ & $\begin{array}{l}0.2-4.8 \\
1.8 \\
(n=103)\end{array}$ & $\begin{array}{l}-28.7 \text { to }-23.9 \\
-26.1 \\
(n=112)\end{array}$ & $\begin{array}{l}58.40-12.15 \\
(n=44)\end{array}$ \\
\hline Muostakh Island & $0-23$ & $\begin{array}{l}59-136 \\
108 \\
(n=7)\end{array}$ & $\begin{array}{l}2.2-9.4 \\
5.0 \\
(n=10)\end{array}$ & $\begin{array}{l}33-336 \\
126 \\
(n=11)\end{array}$ & $\begin{array}{l}5-23 \\
17 \\
(n=12)\end{array}$ & $\begin{array}{l}0.8-11.1 \\
3.5 \\
(n=12)\end{array}$ & $\begin{array}{l}5.2-19.0 \\
9.6 \\
(n=12)\end{array}$ & $\begin{array}{l}0.05-1.7 \\
1.05 \\
(n=12)\end{array}$ & $\begin{array}{l}-27.56 \text { to }-23.12 \\
-25.26 \\
(n=12)\end{array}$ & $\begin{array}{l}46.8-19.6 \\
(n=6)\end{array}$ \\
\hline Stolbovoy Island & $0-27$ & $\begin{array}{l}39-170 \\
72 \\
(n=15)\end{array}$ & $\begin{array}{l}1.7-2.6 \\
2.2 \\
(n=10)\end{array}$ & $\begin{array}{l}18-52 \\
36 \\
(n=12)\end{array}$ & $\begin{array}{l}31-100 \\
69 \\
(n=17)\end{array}$ & $\begin{array}{l}0.7-8.8 \\
2.2 \\
(n=17)\end{array}$ & $\begin{array}{l}6.3-38.4 \\
12.7 \\
(n=17)\end{array}$ & $\begin{array}{l}0.8-5.9 \\
2.6 \\
(n=16)\end{array}$ & $\begin{array}{l}-28.32 \text { to }-23.31 \\
-25.32 \\
(n=10)\end{array}$ & $\begin{array}{l}>55-36.6 \\
(n=7)\end{array}$ \\
\hline $\begin{array}{l}\text { Bel'kovsky Island/ } \\
\text { Cape Skalisty }\end{array}$ & $0-13$ & $\begin{array}{l}68-88 \\
81 \\
(n=4)\end{array}$ & $\begin{array}{l}1.3-2.8 \\
2.4 \\
(n=11)\end{array}$ & $\begin{array}{l}26-44 \\
35 \\
(n=13)\end{array}$ & $\begin{array}{l}11-51 \\
35 \\
(n=7)\end{array}$ & $\begin{array}{l}0.5-2.6 \\
1.1 \\
(n=7)\end{array}$ & $\begin{array}{l}0.3-11.5 \\
6.3 \\
(n=7)\end{array}$ & $\begin{array}{l}2-17 \\
5.7 \\
(n=5)\end{array}$ & $\begin{array}{l}-30.03 \text { to }-26.09 \\
-26.86 \\
(n=14)\end{array}$ & $\begin{array}{l}54.4-40.0 \\
(n=4)\end{array}$ \\
\hline $\begin{array}{l}\text { N Kotel'ny Island/ } \\
\text { Cape Anisii }\end{array}$ & $0-2 \mathrm{~m}$ depth & No data & $\begin{array}{l}2.7-3.2 \\
3.0 \\
(n=3)\end{array}$ & $\begin{array}{l}19-43 \\
28 \\
(n=3)\end{array}$ & $\begin{array}{l}19 \\
(n=3)\end{array}$ & $\begin{array}{l}2.2-5.0 \\
3.4 \\
(n=3)\end{array}$ & $\begin{array}{l}8.5-11.6 \\
9.5 \\
(n=3)\end{array}$ & $\begin{array}{l}0.6 \\
(n=1)\end{array}$ & $\begin{array}{l}-26.27 \text { to }-25.97 \\
-26.10 \\
(n=3)\end{array}$ & $\begin{array}{l}27.9 \\
(n=1)\end{array}$ \\
\hline $\begin{array}{l}\text { SW Kotel'ny Island/ } \\
\text { Khomurganakh } \\
\text { River mouth }\end{array}$ & $0-10$ & $\begin{array}{l}50-155 \\
78 \\
(n=10)\end{array}$ & $\begin{array}{l}2.0-2.8 \\
2.3 \\
(n=7)\end{array}$ & $\begin{array}{l}17-51 \\
28 \\
(n=8)\end{array}$ & $\begin{array}{l}10-62 \\
37 \\
(n=10)\end{array}$ & $\begin{array}{l}0.7-5.3 \\
2.5 \\
(n=6)\end{array}$ & $\begin{array}{l}7.2-21.5 \\
13.9 \\
(n=6)\end{array}$ & $\begin{array}{l}0.1-0.3 \\
0.2 \\
(n=2)\end{array}$ & $\begin{array}{l}-26.85 \text { to }-24.76 \\
-26.65 \\
(n=7)\end{array}$ & $\begin{array}{l}52.8-35.4 \\
(n=4)\end{array}$ \\
\hline $\begin{array}{l}\text { Maly Lyakhovsky } \\
\text { Island }\end{array}$ & $0-5 \mathrm{~m}$ depth & $\begin{array}{l}74-132 \\
86 \\
(n=6)\end{array}$ & $\begin{array}{l}2.3-3.8 \\
2.7 \\
(n=8)\end{array}$ & $\begin{array}{l}14-34 \\
25 \\
(n=8)\end{array}$ & $\begin{array}{l}19-56 \\
32 \\
(n=9)\end{array}$ & $\begin{array}{l}1.6-5.3 \\
2.3 \\
(n=9)\end{array}$ & $\begin{array}{l}4.2-17.4 \\
10.4 \\
(n=9)\end{array}$ & $\begin{array}{l}0.1-1.4 \\
1.5 \\
(n=4)\end{array}$ & $\begin{array}{l}-27.68 \text { to }-24.47 \\
-26.23 \\
(n=9)\end{array}$ & $\begin{array}{l}34.7-28.0 \\
(n=2)\end{array}$ \\
\hline $\begin{array}{l}\text { Bol'shoy } \\
\text { Lyakhovsky } \\
\text { Island }\end{array}$ & $7-27$ & $\begin{array}{l}40-166 \\
82 \\
(n=83)\end{array}$ & $\begin{array}{l}2.2-3.7 \\
3.1 \\
(n=30)\end{array}$ & $\begin{array}{l}13-31 \\
19 \\
(n=42)\end{array}$ & $\begin{array}{l}6-67 \\
25 \\
(n=77)\end{array}$ & $\begin{array}{l}0.4-26.5 \\
5.5 \\
(n=82)\end{array}$ & $\begin{array}{l}1.3-26.8 \\
10.9 \\
(n=60)\end{array}$ & $\begin{array}{l}0.1-2.3 \\
0.7 \\
(n=64)\end{array}$ & $\begin{array}{l}-29.12 \text { to }-24.48 \\
-26.54 \\
(n=77)\end{array}$ & $\begin{array}{l}>55-28.5 \\
(n=20)\end{array}$ \\
\hline $\begin{array}{l}\text { Cape Svyatoy } \\
\text { Nos }\end{array}$ & $9-24$ & No data & No data & $\begin{array}{l}43-208 \\
78 \\
(n=14)\end{array}$ & $\begin{array}{l}14-46 \\
33 \\
(n=14)\end{array}$ & $\begin{array}{l}0.5-3.6 \\
1 \\
1.2 \\
(n=14)\end{array}$ & $\begin{array}{l}4.1-11.2 \\
6.3 \\
(n=14)\end{array}$ & $\begin{array}{l}0.9-1.9 \\
1.3 \\
(n=12)\end{array}$ & No data & $>50-36.1$ \\
\hline $\begin{array}{l}\text { Oyogos Yar } \\
\text { coast }\end{array}$ & $9-28$ & $\begin{array}{l}24-242 \\
114 \\
(n=19)\end{array}$ & $\begin{array}{l}2.4-4.2 \\
3.4 \\
(n=31)\end{array}$ & $\begin{array}{l}17-53 \\
30 \\
(n=35)\end{array}$ & $\begin{array}{l}9-26 \\
15 \\
(n=35)\end{array}$ & $\begin{array}{l}1.1-8.1 \\
2.8 \\
(n=35)\end{array}$ & $\begin{array}{l}2.8-22.1 \\
7.3 \\
(n=33)\end{array}$ & $\begin{array}{l}1.8-18.7 \\
5.6 \\
(n=32)\end{array}$ & $\begin{array}{l}-24.9 \text { to }-31.1 \\
-27.7 \\
(n=30)\end{array}$ & $\begin{array}{l}48.8-34.6 \\
(n=4)\end{array}$ \\
\hline
\end{tabular}

et al., 2004). The Ice Complex likely represents a large permafrost carbon pool if broad regional upscaling is applied (Zimov et al., 2006; Tarnocai et al., 2009). According to several paleobotanical analyses (Andreev et al., 2002, 2009; Schirrmeister et al., 2003b, 2008a,b; Kienast et al., 2005; Wetterich et al., 2008) the organic matter composition of Ice Complex sequences seems to be dominated by plant material from herbs (e.g. Artemisia, Carophyllaceae, Asteraceae), grasses (e.g. Poacea, Cyperacea), and to a smaller extent from some dwarf shrubs (e.g. Salix, Alnus, Betula). The average organic carbon content ranges from 1.2 to $4.8 \mathrm{wt} \% . \delta^{13} \mathrm{C}$ values range from about -24 to $-29 \%$ indicating that only freshwater aquatic and sub-aerial terrestrial environments participated in Ice Complex formation. These values reflect the dominance of terrestrial $\mathrm{C} 3$ plants within the organic matter. Variations in TOC content, $\mathrm{C} / \mathrm{N}$ ratio, and $\delta^{13} \mathrm{C}$ values are connected to changes in bioproductivity, intensity and character of cryosol formation, different degrees of organic matter decomposition, as well as variations in plant associations. High TOC contents, high $\mathrm{C} / \mathrm{N}$ ratios, and low $\delta^{13} \mathrm{C}$ values reflect less-decomposed organic matter under anaerobic conditions, which is characteristic of Middle Weichselian interstadial periods. Stadial periods are characterized by less variable, generally low TOC contents indicating stable environments with reduced bioproductivity, and glacial periods by low $\mathrm{C} / \mathrm{N}$ ratios. High $\delta^{13} \mathrm{C}$ values reflect relatively dry, aerobic conditions.

Heavy mineral analyses revealed significant differences in detrital composition between various sites (Table 3 ) pointing to different and primarily local sediment sources. This directly contradicts the idea of uniform regional formation, and severely weakens the general idea of a pure aeolian origin of Ice Complex sequences.

Numerous grain size analyses show that the fine-grained sediments of Ice Complex deposits are poorly sorted and differ in grain 

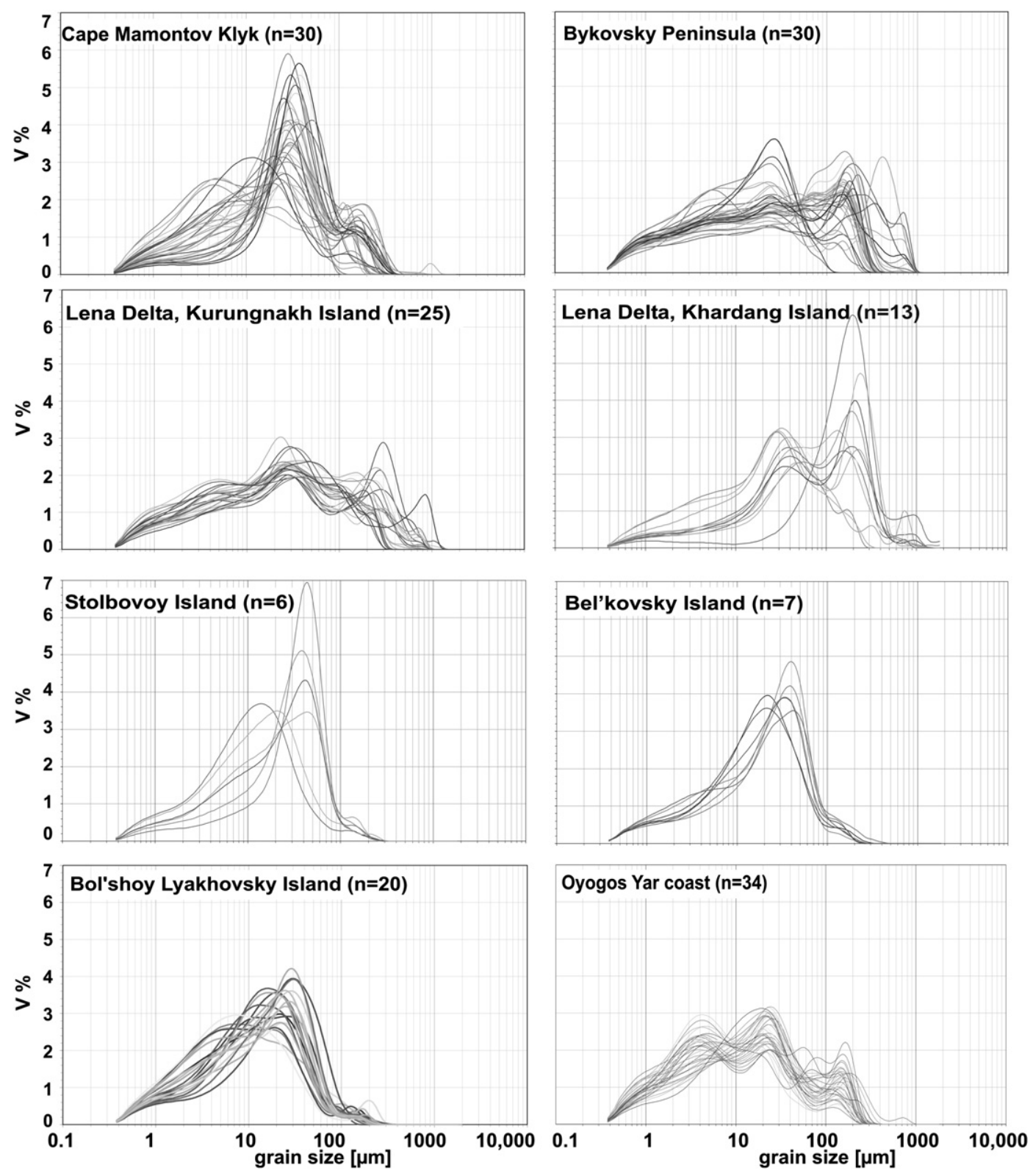

Fig. 15. Grain size distribution patterns of different Ice Complex sections

size parameters (Table 5, Fig. 15, 16) from site to site as well as within horizons of one particular site. Multimodal grain size distributions in various patterns are revealed (Fig. 15), indicating the participation of various processes of transport, accumulation, and re-sedimentation in Ice Complex formation in agreement with a polygenetic formation concept. The grain size distribution appears also to reflect a clear aeolian component. However, the occurrence of the silt-sized fraction in the wide grain size spectra was dominantly caused by on-site frost weathering processes (Konishchev and Rogov, 1993). Repeated freezing and thawing of ice-supersaturated sediment results in creation of silt particles. Hence, the presence of a pronounced silt fraction in permafrost deposits can be not automatically regarded an indicator for loess.

According to Pye (1984), loess is characterized by windblown silt deposits consisting chiefly of quartz, feldspar, mica, clay minerals, and carbonate grains. By definition, loess is typically a homogeneous, non-stratified, and highly porous deposit (Jackson, 1997, p. 375 ). The grain size distribution of typical loess shows a pronounced mode in the range of $20-40 \mu \mathrm{m}$ and positively skewed. These properties of loess clearly do not correspond with the characteristics of Ice Complex records studied at 14 sites in the Laptev Sea region of North Siberia. Usually, loess formation is explained in connection with glacial processes (e.g., Seppälä, 2004) and loess deposits are distributed in the vicinity of glaciers, ice sheets, or large fluvial outwash plains; apart from small mountain valley glaciers, neither glaciers nor ice sheets existed in the studied region of western Beringia during the Late Pleistocene (Hubberten et al., 2004; Svendsen et al., 2004), and the mineralogical composition of the Ice Complex speaks for a local sediment source versus that of an fluvial outwash plain with a distal mineralogical signal.

\subsection{Geochronology and stratigraphy}

The age of Ice Complex sequences was determined by radiocarbon AMS analysis of mostly plant remains from about 300 samples and several in situ mammal bones. A maximum age for the 


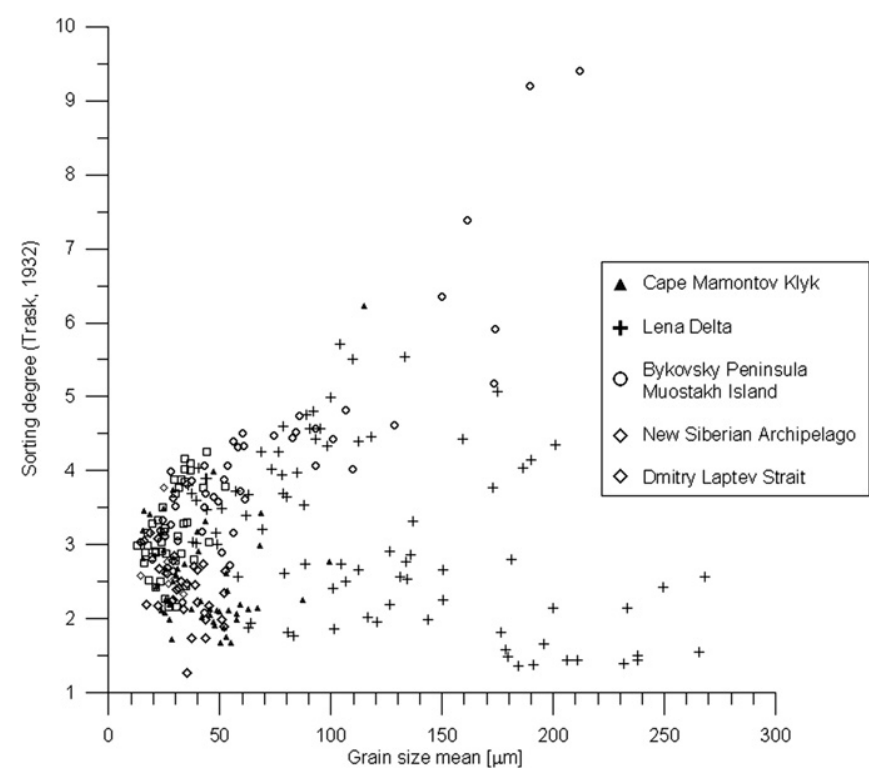

Fig. 16. Grain size mean and sorting degree (Trask, 1932) of Ice Complex deposits from five Ice Complex provinces in the study region. Cape Mamontov Klyk (50); Lena Delta: Khardang-Sise Island (33), Ebe-Sise Island (14), Kurungnakh Sise Island (37); Bykovsky Peninsula (47), Muostakh Island (10); New Siberian Archipelago: Stolbovoy Island (17), Dmitry Laptev Strait (61) (the number of samples per site is given in brackets

Ice Complex sedimentation was determined by several studies using ${ }^{230} \mathrm{Th} / \mathrm{U}$ for dating peat horizons, and thermo-luminescence and infrared optical stimulated luminescence for dating the burial of sediment horizons found below the Ice Complex. The Ice Complex at sites in the western Laptev Sea and Lena Delta regions is mostly underlain by fluvial sands with peat layers, which were ${ }^{230} \mathrm{Th} / \mathrm{U}$ - and luminescence-dated to about 60-100 ka (Krbetschek et al., 2000; Schwamborn et al., 2002; Schirrmeister et al., 2003b, 2008a; Wetterich et al., 2008). Eemian interglacial deposits of lacustrine origin or loess-like floodplain deposits (luminescencedated to about $100 \mathrm{ka}$ ) are evident below the Ice Complex at sites along the Dmitry Laptev Strait (Andreev et al., 2004, 2009; Wetterich et al., 2009). Based on the AMS radiocarbon dates, the initiation of Ice Complex formation (Table 5) varies from $>55$ ka BP on the New Siberian Islands to about $27 \mathrm{ka}$ BP at Cape Mamontov Klyk on the western Laptev Sea coast. The rather long sequence at Mamontovy Khayata on the Bykovsky Peninsula allows an extrapolation of relatively stable sedimentation rates and age based on a well-constrained age vs. elevation relation, indicating an estimated initiation of Ice Complex formation at this site at around 80 ka BP (Schirrmeister et al., 2002a).

The internal stratification of Ice Complex sequences varies from site to site (Fig. 17). In some cases the Ice Complex covers only the Middle Weichselian interstadial period, or only the Late Weichselian Glacial period, or both. In other cases Ice Complex sequences expose sediments continuously deposited from the Early to Late Weichselian times (e.g. Mamontovy Khayata on Bykovsky Peninsula).

The uppermost boundary of Ice Complex sequences as dated with the AMS radiocarbon method (Table 5) differs between $28 \mathrm{ka}$ BP on the New Siberian Islands and 17-13 ka BP in various other sites. Observed stratigraphic gaps atop the Ice Complex of up to $20 \mathrm{ka}$ are very likely caused by post-depositional events, namely widespread thermokarst processes and thermo-erosion. Important support for this hypothesis comes from the presence of numerous relocated mammal bones of the mammoth fauna at these questionable sites whose radiocarbon dates fit into these stratigraphic gaps (Sher et al., 2005; Andreev et al., 2009). In addition, the entire Laptev Sea region is seismotectonically active with a rift system in the eastern Laptev shelf separating the Eurasian and North American plates. The rift is accompanied by several tectonic blocks that moved vertically on Pleistocene and Holocene time scales (Drachev et al., 1998; Franke et al., 2000). Stratigraphical gaps could likely be caused by vertical changes in these horst and graben systems that effected sediment transport, accumulation and erosion processes. The upper boundary of the Ice Complex at all sites is characterized by separate, spatially confined Holocene deposits on top of the Ice Complex sequences. These deposits accumulated in small initial thermokarst depressions or thaw ponds and are mostly less than $2 \mathrm{~m}$ thick.

According to numerous paleoecological, especially paleobotanical, records (Andreev et al., 2002, 2004, 2009; Schirrmeister et al., 2002a, 2003b, 2008a; Kienast et al., 2005; Sher et al., 2005; Grosse et al., 2006; Wetterich et al., 2008) the period of Ice Complex formation in the study region was characterized by (I) sparse grasssedge tundra growing in an extremely cold and dry climate during the Early Weichselian glacial; (II) tundra-steppe vegetation with high bioproductivity in a more moderate and relatively humid climate during the Middle Weichselian interstadial; and (III) sparse grass-tundra present in an extreme, cold climate during the Late Weichselian glacial period. The extreme continental climate conditions during the Weichselian were connected to the presence of a largely exposed shelf area, a very likely perennial Arctic sea ice cover, and the existence of a huge Eurasian ice sheet to the west (Hubberten et al., 2004; Svendsen et al., 2004). Nevertheless, various algae spores and remains of other aquatic organisms found in many Ice Complex samples indicate the existence of small freshwater bodies. In addition, numerous fossil bones as well as spores from dung-inhabiting fungi indicate the widespread occurrence of mammoth fauna species, which had an optimum during the Middle Weichselian interstadial period.

\subsection{Conceptual model of nival lithogenesis}

The concept of nival lithogenesis was proposed by Kunitsky (1993) and comprehensively explained by Kunitsky (2007). It combines essential cold climate geological and geomorphological processes (Fig. 18) to explain the Ice Complex as a characteristic periglacial facies.

Initially, windblown snow together with plant and mineral detritus accumulated in numerous perennial snowfields (névés) in topographically protected zones of hills and low mountain ranges (e.g. steep slopes, valleys, cryoplanation terraces; Fig. 18a). In addition to this aeolian transport, more silt-sized mineral detritus was produced by intense frost weathering around the snowfields. On a smaller scale, similar phenomena can be observed today on numerous slopes and terrain steps in northern East Siberia where nivation is an essential geomorphological factor (Kunitsky et al., 2002). The role of nivation for arctic landscape dynamics is also discussed by Thorn and Hall (2002).

These perennial snowfields accumulated high amounts of plant and clastic detritus. Due to repeating processes of snowfield accumulation, snow melt, and meltwater transport over thousands of years, the downslope areas became enriched with fine-grained sediments containing plant detritus and mineral debris and eventually extended into wider accumulation plains. Intense freeze-thaw cycles and wet conditions around and below the perennial snowfields support the formation of fine-grained material by frost weathering (Fig. 18b) (Konishchev, 1982, 1987; Konishchev and Rogov, 1993).

Transport of this clastic and organic matter detritus from snowfield zones proceeded via seasonal meltwater runoff (Fig. 18c). Fine-grained debris was subsequently distributed by alluvial, fluvial, proluvial, and also aeolian transport to foreland plains, cryoplanation terraces or large alluvial fans. Therefore, different 


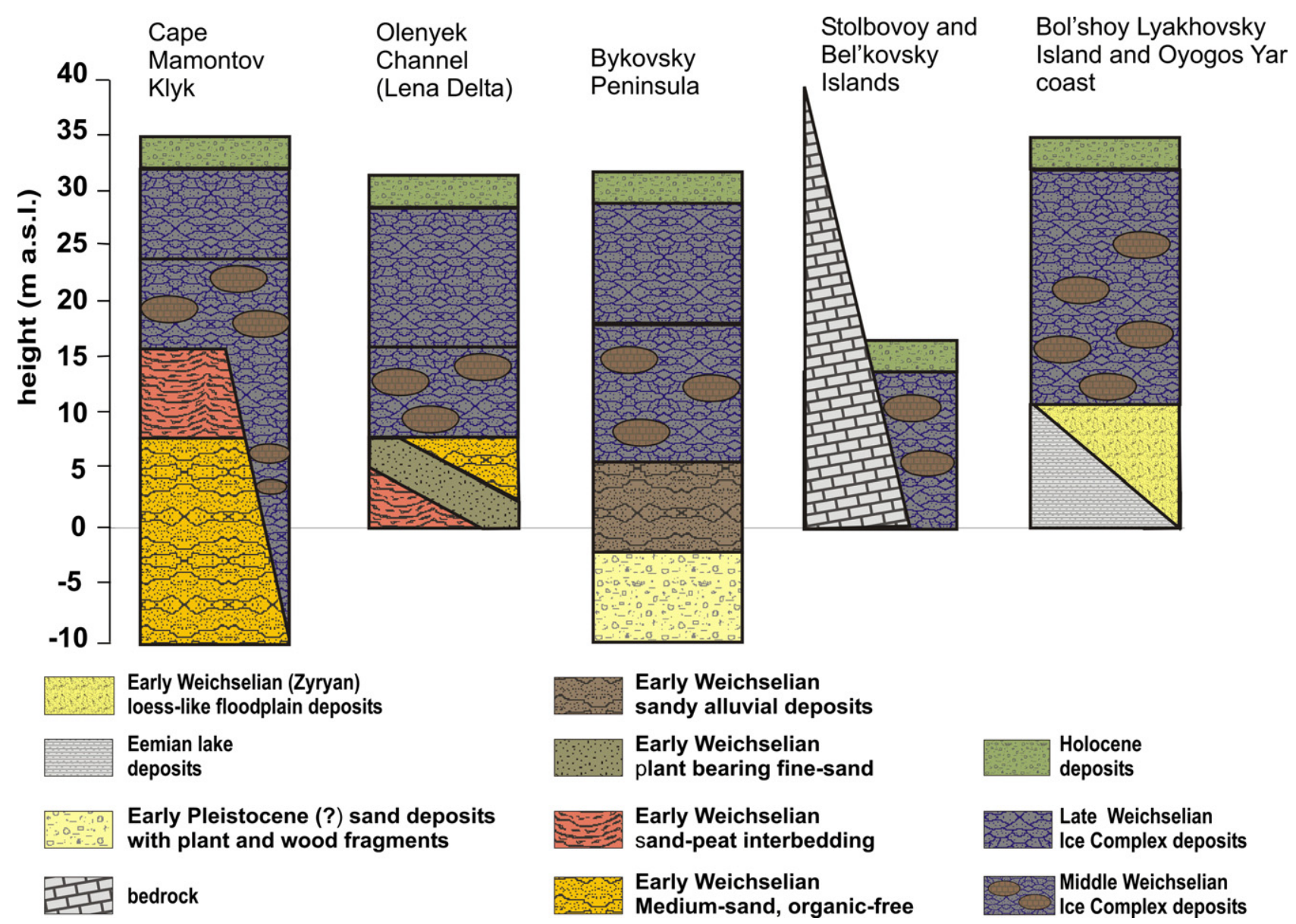

Fig. 17. Generalized lithostratigraphic schemes.

types of Ice Complex deposits and variable grain size distribution patterns are found at different sites depending on local landscape conditions.

Finally, polygonal ice wedge systems (Fig. 18d) developed syngenetically with ongoing sediment deposition in the flat accumulation plains. The typical Ice Complex formation consists of several concurrent cryogenic processes including sediment accumulation and freezing, ground ice segregation, syngenetic ice wedge growth, sediment reworking, peat aggradation, cryosol formation, and cryoturbation, all promoted by long-lasting harsh continental conditions.

\subsection{General consideration and some recommendations}

These interpretations of North Siberian Ice Complex genesis, since based on a large number of field studies, sites, and samples, are more comprehensive than previous hypotheses and even falsify some previous approaches. In contrast to the pure aeolian (Tomirdiaro, 1996) or glacial (Grosswald, 1998) hypotheses, the proposed concept of nival lithogenesis integrates several of the previously proposed formation concepts. The concept of nival lithogenesis corresponds to the polygenetic character of Ice Complex formation presented by Sher (1997) and Sher et al. (2005). However, it also describes several sediment sources, weathering processes, and pathways by which sediments in typical periglacial landscapes can build up the Ice Complex under extreme cold climatic conditions. The concept of nival lithogenesis explains Ice Complex formation in a more profound way. Because of the heterogeneity of studied Ice Complex sequences (Tables 3 and 5), the existence of "a continuous loess-covered land surface underlain by permanently frozen sea ice" as stated by Tomirdiaro (1996) is not supported by this study. Other conclusions and applications of the concept of aeolian origin of the Ice Complex have to be considered cautiously. The widespread pure aeolian hypothesis for the Ice Complex (e.g., cited in Brigham-Grette, 2001) is also used for climate simulations. For example, an albedo-decreasing glacial loess-dust cover on seasonal snow is assumed for non-glaciated Siberia during the Last Glacial Maximum in some climate models (e.g., Krinner et al., 2006) in order to explain the lack of ice shields in northern Asia. Another example is the calculation of aeolian mass accumulation rates (MARs) in the Yakutian region from 25-12 ka BP (Mahowald et al., 2006). Other concepts of the Ice Complex present in the current literature misinterpret previous results. Archer (2007, p. 531), when discussing potential occurrence of methane hydrates in permafrost refers to the Ice Complex in Siberia: [Total amounts of hydrate methane in permafrost soils are very poorly known ... There is a special case called the ice complex in Siberia .... The ice complex is a sealed horizon of ice that was formed when sea level was as much as $120 \mathrm{~m}$ lower than today, during the last glacial maximum. Liquid ground water froze as it flowed through the permafrost, creating a sealed layer up to 60-80 m thick, onshore and offshore under as much as $100 \mathrm{~m}$ water depth].

Finally, the Ice Complex sediments are viewed as a major carbon pool based on general assumptions about distribution, thickness, organic carbon content, and ice content (Zimov et al., 2006; Tarnocai et al., 2009). Based on the datasets showing strong regional heterogeneity of Ice Complex characteristics, such first order calculations should be refined in future studies. Available maps of potential Ice Complex distribution need to be updated with 

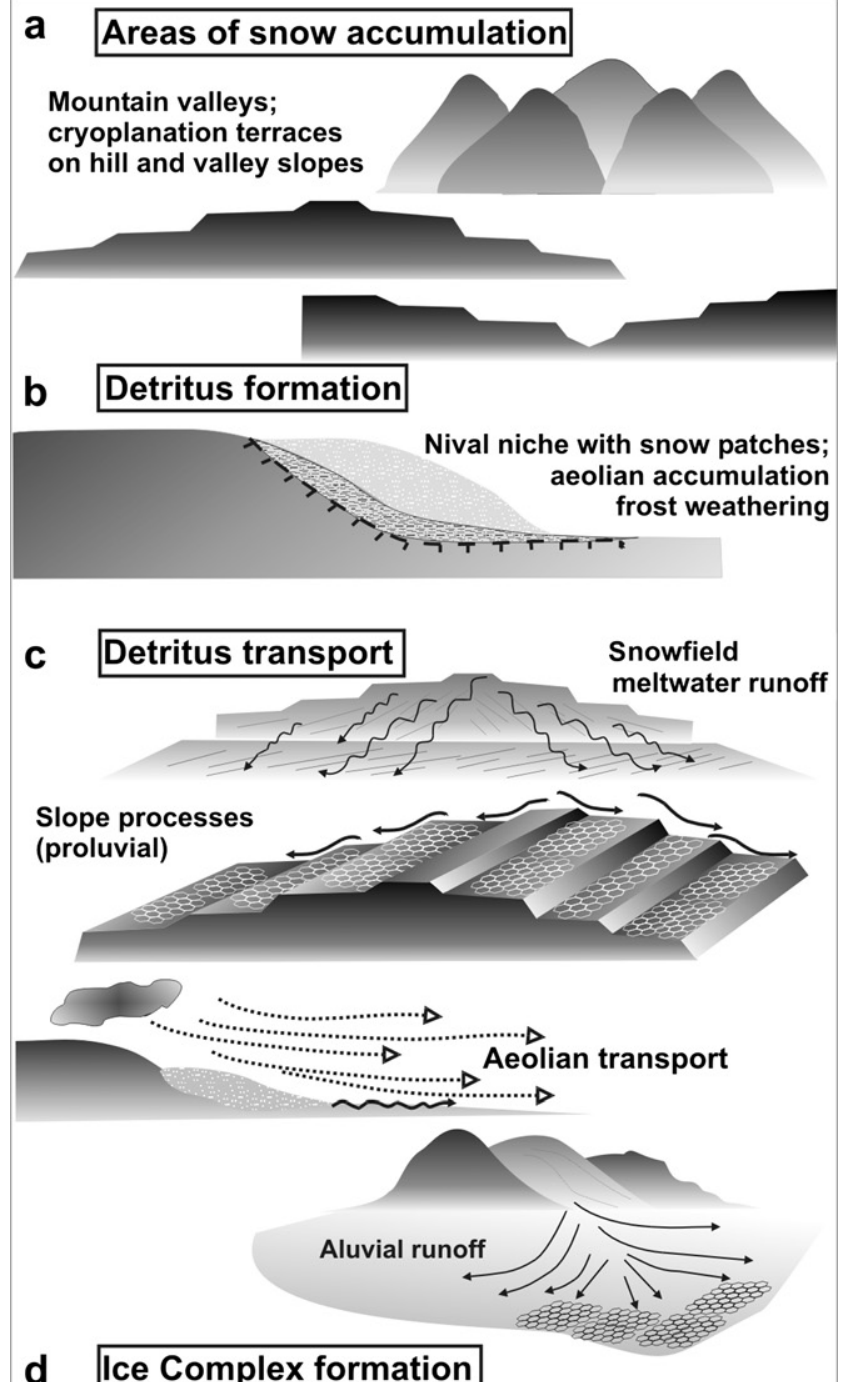

\section{d Ice Complex formation}

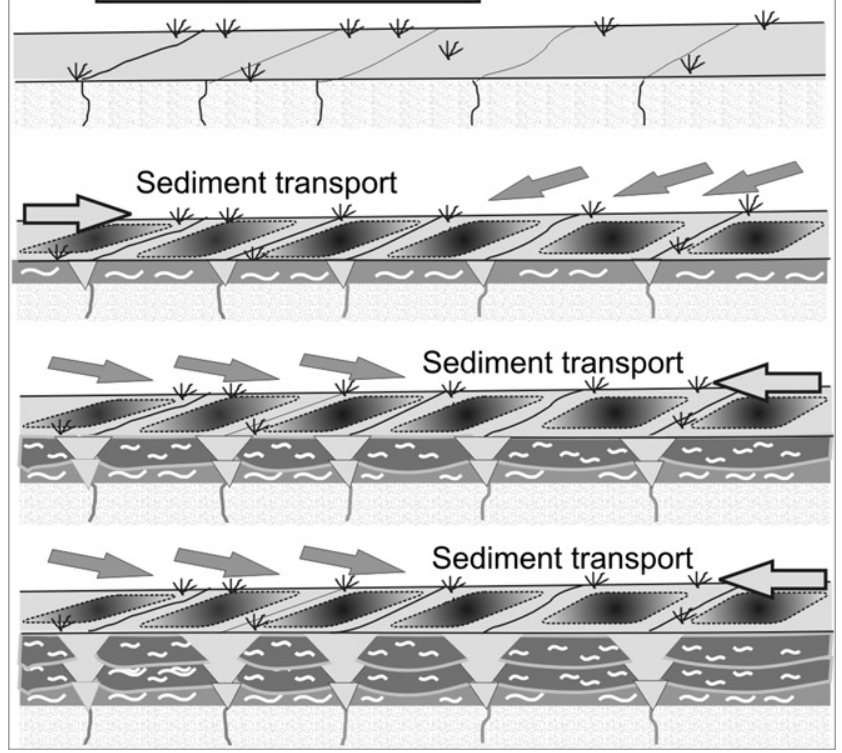

Fig. 18. Stages of Ice Complex formation according to the concept of nival lithogenesis $(\mathrm{a}-\mathrm{d})$ and the interpreted Late Pleistocene landscape situation. higher-resolution data and especially with more field data. In addition, the modern distribution of thermokarst needs to be taken into account when quantifying the remaining Ice Complex deposits and the Ice Complex carbon pool.

\section{Conclusions}

(1) The formation of huge polygonal syngenetic ice wedge systems and thick continuous sequences of ice-rich deposits is closely related to the persistence of stable, poorly drained, low-topographic-gradient accumulation plains and perennial snowfields on edges of cryoplanation terraces and in ranges of low hills.

(2) The accumulation of Ice Complex sequences during the Late Pleistocene was promoted by the absence of large glaciers and ice sheets and the long-term stable cold climate conditions.

(3) The Ice Complex is a frozen deposit defined by certain cryolithological and sedimentological characteristics and preserved today in elevated erosional remnants in thermokarst landscapes termed Yedoma hills as well as on cryoplanation terraces.

(4) The Ice Complex has to be considered as a special kind of periglacial or cryogenic facies, typical of the Late Pleistocene period in western Beringia.

(5) In this sense, the Ice Complex cover in East Siberian arctic lowlands could be considered to be a chronological and stratigraphical, but not genetic, equivalent of typical Late Pleistocene loess belt occurring in the northern mid latitudes or near glaciers and ice sheets.

\section{Acknowledgments}

This study is part of the Russian-German science collaboration "Laptev Sea System" supported by several projects of the German Ministry of Science and Education and the German Science Foundation (DFG) as well as the Russian Foundation of Basic Research (RFBR) during the last 12 years. Guido Grosse was additionally supported by NSF ARCSS grant \#0732735. We thank all Russian and German colleagues who helped us during fieldwork in Siberia since 1998. The analytical work in the laboratories at the Alfred Wegener Institute Potsdam was greatly supported by Ute Bastian, and Lutz Schönicke. The paper really benefited by valuable comments and English language correction from Candace O'Connor (University of Alaska, Fairbanks). We thank both anonymous reviewers for their critical discussion of the manuscript and valuable comments that enhanced the paper.

\section{Appendix. Supplementary online material (SOM 1)}

Cryostructure of Ice Complex sequences.

A: Thermokarst mound with buried cryosol sequences at Oyogos Yar; B: Thermokarst mound with a peaty cryosol between ice wedge (B. Lyakhovsky Island); C: Syngenetic ice wedge with ice bands (B. Lyakhovsky Island); D: Syngenetic ice wedge with ice bands and ice-rich interbeds (Bykovsky Peninsula); E, F: Buried cryosols at Cape Mamontov Klyk; G, H: Reticulated ice structures between ice bands (B. Lyakhovsky Island). Supplementary data associated with this article can be found in the online version, at doi:10.1016/j.quaint.2010.04.004.

\section{References}

Adams, M., 1807. Some account of a journey to the frozen sea, and of the discovery of the remains of a mammoth. Philosophical Magazine 29, 141-143. 
Andreev, A.A., Schirrmeister, L., Siegert, C., Bobrov, A.A., Demske, D., Seiffert, M. Hubberten, H.-W., 2002. Paleoenvironmental changes in north-eastern Siberia during the Late Quaternary-evidence from pollen records of the Bykovsky Peninsula. Polarforschung 70, 13-25.

Andreev, A.A., Grosse, G., Schirrmeister, L., Kuzmina, S.A., Novenko, E.Yu., Bobrov, A. A., Tarasov, P.E., Kuznetsova, T.V., Krbetschek, M., Meyer, H., Kunitsky, V.V., 2004 Late Saalian and Eemian palaeoenvironmental history of the Bol'shoy Lyakhovsky Island (Laptev Sea region, Arctic Siberia). Boreas 33, 319-348.

Andreev, A., Grosse, G., Schirrmeister, L., Kuznetsova, T.V., Kuzmina, S.A., Bobrov, A A., Tarasov, P.E., Novenko, E.Yu., Meyer, H., Derevyagin, A.Yu., Kienast, F., Bryantseva, A., Kunitsky, V.V., 2009. Weichselian and Holocene palaeoenvironmental history of the Bol'shoy Lyakhovsky Island, New Siberian Archipelago. Arctic Siberia. Boreas 38, 72-110.

Archer, D., 2007. Methane hydrate stability and anthropogenic climate change Biogeosciences 4, 521-544.

Arkhangelov, A.A., Mikhalev, D.V., Nikolaev, V.I., 1996. About early epochs of permafrost formation in northern Yakutia and age of ancient relicts of underground glaciation. In: Velichko, A.A., Arkhangelov, A.A., Borisova, O.K. Gribchenko, Y.N., Drenova, A.N., Zelikson, E.M., Kurenkova, E.N., Mikhalev, D.V. Nikolaev, V.I., Novenko, E.Y., Timireva, S.A. (Eds.), Razvitie oblasti mnnogoletne merzloty i periglyatsial'noi zony Severnoi Evrazii i usloviya rasseleniya drevnego cheloveka. Institute of Geography, Moscow, pp. 102-109 (in Russian).

Baranova, Yu.P., Biské, S.F., 1964. North East USSR (History of Relief Formation in Siberia and Far East). Nauka Press, Moscow (in Russian), p. 290.

Bobrov, A.A., Andreev, A.A., Schirrmeister, L., Siegert, C., 2004. Testate amoebae (Protozoa: Testacealobosea and Testaceafilosea) as bioindicators in the Late Quaternary deposits of the Bykovsky Peninsula, Laptev Sea, Russia. Palaeogeography, Palaeoclimatology, Palaeoecology 209, 165-181.

Bobrov, A.A., Müller, S., Chizhikova, N.A., Schirrmeister, L., Andreev, A.A., 2009 Testate Amoebae in Late Quaternary sediments of the Cape Mamontov Klyk (Yakutia). Biology Bulletin 36 (4), 363-372.

Brigham-Grette, J., 2001. New perspectives on Beringian Quaternary paleogeography, stratigraphy, and glacial history. Quaternary Science Reviews 20, 15-24.

Bunge, A.A., 1887. Bericht ueber den ferneren Gang der Expedition. Reise nach den Neusibirischen Inseln. Aufenthalt auf der Grossen Ljachof-Insel. In: Schrenk, L. V., Maximovicz, C.J. (Eds.), Expedition zu den Neusibirischen Inseln und dem Jana-Lande (1885). Beitraege zur Kenntnis des russischen Reiches und der angrenzenden Laender, vol. III, pp. 231-284.

Bunge, A.A., 1895. The Lena expedition 1881-1884. In: Tillo, A. (Ed.), Observations of the Russian polar station at the Lena mouth, Beobachtungen der russischen Polarstation an der Lenamündung. Expedition der Kaiserlichen Russischen Geographischen Gesellschaft, St. Petersburg, pp. 1-96.

Colinvaux, P.A., 1996. Reconstructing the environment. In: West, C.F. (Ed.), American Beginnings: The Prehistory and Palaeoecology of Beringia. University of Chicago Press, Chicago, pp. 13-19.

Dostovalov, B.N., Kudryavtsev, V.A., 1967. General geocryology (Obshchee mersotovedenie). Moscow University Publishing House, Izdatel'stvo Moskovkogo Universiteta, p. 403.

Drachev, S.S., Savostin, L.A., Groshev, V.G., Bruni, I.E., 1998. Structure and geology of the continental shelf of the Laptev Sea, Eastern Russian Arctic. Tectonophysics 298, 357-393.

van Everdingen, R.O. (Ed.), 1998. Multi-language Glossary of Permafrost and Related Ground-ice Terms. Arctic Institute of North America, University of Calgary, Calgary.

Franke, D., Hinz, K., Block, M., Drachev, S.S., Neben, S., Kos'ko, M.K., Reichert, C Roeser, H.A., 2000. Tectonics of the Laptev Sea region in Northeastern Siberia. Polarforschung 68, 51-58.

Frenzel, B., Pecsi, M., Velichko, A.A., 1992. Atlas of Paleoclimates and Paleoenvironments of the Northern Hemisphere: Late Pleistocene-Holocene. Geographical Research Institute, Hungarian Academy of Sciences/Gustav Fischer Verlag, Budapest/Stuttgart, $156 \mathrm{p}$.

Fukuda, M., 1994. Occurrence of Ice-Complex (edoma) in Lena River Delta Region and Big Lyakhovsky Island. High Arctic eastern Siberia. In: Inoue, G. (Ed.) Proceedings of the 2nd Symposium on the Joint Siberian Permafrost Studies Between Japan and Russia, pp. 5-13.

Galabala, R.O., 1997. Pereletki and the initiation of glaciation in Siberia. Quaternary International 41/42, 27-32.

Gilichinsky, D.A., Nolte, E., Basilyan, A.E., Beer, J., Blinov, A.V., Lazarev, V.E. Kholodov, A.L., Meyer, H., Nikolskiy, P.A., Schirrmeister, L., Tumskoy, V.E. 2007. Dating of syngenetic ice wedges in permafrost with $36 \mathrm{Cl}$. Quaternary Science Reviews 26, 1547-1556.

Gravis, G.F., 1969. Slope Deposits in Yakutia. Nauka Press, Moscow, pp. 128 (in Russian).

Gravis, G.F., 1978. Cyclicity of thermokarst at the coastal lowlands during the late Pleistocene and Holocene. In: Publications of the 3rd International Permafrost Conference, July 10-13 1978, Edmonton, Alberta, Canada, vol. 1, pp. 283-287.

Grigoriev, M.N., Imaev, V.S., Kozmin, B.M., Kunitsky, V.V., Larionov, A.G. Mikulenko, K.I., Skrjabin, R.M., Timirsin, K.V., 1996. Geology, Seismicity and Cryogenic Processes in the Arctic Areas of Western Yakutia. Yakutian Scientific Centre SB RAS, Yakutsk (in Russian).

Grootes, P.M., Nadeau, M.J., Rieck, A., 2004. 14C-AMS at the Leibniz-Labor: radiometric dating and isotope research. Nuclear Instruments and Methods in Physics Research 223, 55-61.

Grosse, G., Schirrmeister, L., Kunitsky, V.V., Dereviagyn, A., 2003. Periglacial features around Tiksi. Reports on Polar Research 466, 134-191.
Grosse, G., Schirrmeister, L., Kunitsky, V.V., Hubberten, H.-W., 2005. The use of CORONA images in remote sensing of periglacial geomorphology: an illustration from the NE Siberian coast. Permafrost and Periglacial Processes 16, 163-172.

Grosse, G., Schirrmeister, L., Malthus, T.J., 2006. Application of Landsat-7 satellite data and a DEM for the quantification of thermokarst-affected terrain types in the periglacial Lena-Anabar coastal lowland. Polar Research 25, 51-67.

Grosse, G., Schirrmeister, L., Siegert, C., Kunitsky, V., Slagoda, E.A., Andreev, A.A., Dereviagyn, A.Y., 2007. Geological and geomorphological evolution of a sedimentary periglacial landscape in northeast Siberia during the Late Quaternary. Geomorphology 86, 25-51.

Grosswald, M.G., 1998. Late-Weichselian ice sheets in Arctic and Pacific Siberia. Quaternary International 45/46, 3-18.

Hubberten, H.-W., Andreev, A., Astakhov, V.I., Demidov, I., Dowdeswell, J.A Henriksen, M., Hjort, C., Houmark-Nielsen, M., Jakobsson, M., Kuzmina, S., Larsen, E., Lunkka, J.P., Lysa, A., Mangerud, J., Moeller, P., Saarnisto, M., Schirrmeister, L., Sher, A.V., Siegert, C., Siegert, M.J., Svendsen, J.I., 2004. The periglacial climate and environment in northern Eurasia during the last glaciation. Quaternary Science Reviews 23, 1333-1357.

Ilyashuk, B.P., Andreev, A.A., Bobrov, A.A., Tumskoy, V.E., Ilyashuk, E.A., 2006 Interglacial history of a palaeo-lake deposit and regional environment: a multiproxy study of a permafrost deposit from Bol'shoy Lyakhovsky Island, Arctic Siberia. Journal of Paleolimnology 35, 855-872.

Imaev, V.S., Imaeva, L.P., Kozmin, B.M., 2000. Seismo-tectonics of Yakutia. GEOS, Moscow (in Russian).

Ivanov, M.S., Katasonova, E.G., 1978. Percularities of cryolithogenic deposits of Muoastakh Island. Geocryological and Hydrogeological Studies in Yakutia. Permafrost Institute Yakutsk Press, Yakutsk, pp. 12-25 (in Russian)

Jackson, J., 1997. Glossary of Geology, fourth ed. American Geological Institute Alexandria, Virginia, 769 pp.

Kaplina, T.N., Lozhkin, A.V., 1984. Age and history of accumulation of the "Ice Complex" of the maritime lowlands of Yakutiya. In: Velichko, A.A., Wright Jr., H. E., Barnosky, C.W. (Eds.), Late Quaternary Environments of the Soviet Union. University of Minnesota Press, Minneapolis, MN, pp. 147-151.

Kayalainen, V.I., Kulakov, Yu.N., 1966. To the questions of Paleogeography of the Yana-Indigirka coastal lowland during the Neogene-Quaternary period. Quaternary Period in Siberia. Nauka, Moscow, pp. 274-283 (in Russian).

Kienast, F., Schirrmeister, L., Siegert, C., Tarasov, P., 2005. Palaeobotanical evidence for warm summers in the East Siberian Arctic during the last cold stage. Quaternary Research 63, 283-300.

Kienast, F., Tarasov, P., Schirrmeister, L., Grosse, G., Andreev, A.A., 2008. Continental climate in the East Siberian Arctic during the last interglacial: Implications from palaeobotanical records. Global and Planetary Change 60 (3/4), 535-562.

Kolosov, D.M., 1947. Problems of former glaciation of Northeast USSR. In: Reports of the Geological Department of the Major Administration of the Northern Sea Route (GUSMP), vol. 30. Glavsevmorput Publishing House, Moscow, Leningrad, p. 175 (in Russian).

Konishchev, V.N., 1981. Formation of Disperse Composed Deposits of the Cryolithophere. Nauka, Novosibirsk, 198 pp. (in Russian).

Konishchev, V.N., Kolesnikov, S.F., 1981. Specialities of structure and composition of late Cenozoic deposits in the section of Oyogossky Yae. In: Problems of Cryolithology, vol. IX. MGU Publishing, Moscow, pp. 107-117 (in Russian).

Konishchev, V.N., 1982. Characteristics of cryogenic weathering in the permafrost zone of the European USSR. Arctic and Alpine Research 14 (3), 261-265.

Konishchev, V.N., 1987. Origin of loess-like silt in Northern Jakutia, USSR. GeoJournal 15 (2), 135-139 (in Russian).

Konishchev, V.N., Rogov, V.V., 1993. Investigations of cryogenic weathering in Europe and Northern Asia. Permafrost and Periglacial Processes 4, 49-64.

Krbetschek, M.R., Gonser, G., Schwamborn, G., 2002. Luminescence dating results on sediment sequences of the Lena Delta. Polarforschung 70, 83-88.

Krinner, G., Boucher, O., Balkanski, Y., 2006. Ice-free glacial northern Asia due to dust deposition on snow. Climate Dynamics 27, 613-625. doi:10.1007/s00382006-0159-z

Kunitsky, V.V., 1989. Kriolitologiya nizo'ev Leny (Cryolithology of the Lower Lena). Permafrost Institute Press, Yakutsk, 162 pp (in Russian).

Kunitsky, V.V., 1993. On the study of nival deposits in Yakutia. Permafrost. In: Proceedings of the Sixth International Conference on Permafrost. Bejing, vol. 1 pp. 903-910.

Kunitsky, V.V., 1996. Chemical content of ice wedges of the Ice complex. Development of the Cryolithozone of Eurasia During the Upper Cenozoic. RAS, Permafrost Institute, Yakutsk, pp. 93-117 (in Russian).

Kunitsky, V.V., 1998. Ice Complex and cryoplanation terraces of Bol'shoy Lyakhovsky Island. In: Kamensky, R.M., Kunitsky, V.V., Olovin, B.A., Shepelev, V.V. (Eds.) Problems of Geocryology. Collected papers. RAS, Permafrost Institute, Yakutsk, 210 pp. (in Russian).

Kunitsky, V.V., Schirrmeister, L., Grosse, G., Kienast, F., 2002. Snow patches in nival landscapes and their role for the Ice Complex formation in the Laptev Sea coastal lowlands. Polarforschung 70, 53-67.

Kunitsky, V.V., 2007. Nival lithogenesis and Ice Complex on the territory of Yakutia. Abstract of the Doctoral Dissertation. Permafrost Institute, Yakutsk, 46 pp. (in Russian).

Kutzbach, L., Wagner, D., Pfeiffer, E.-M., 2004. Effect of microrelief and vegetation on methane emission from wet polygonal tundra, Lena Delta, Northern Siberia. Biogeochemistry 69, 341-362.

Kuzmina, S., Wetterich, S., Meyer, H., 2003. Paleoecological and sedimentological studies of Permafrost deposits in the Central Lena Delta (Kurungnakh and Samoylov Islands). Reports on Polar and Marine Research 466, 71-81. 
Lopatin, V.G. (Ed.), 1998. State Geological Map of Russian Federation, New Siberian Islands, 1:1,000,000 Map of Pre-Quaternary Formations. Ministry of Natural Resources of Russian Federation.

Mahowald, N.N., Muhs, D.R., Levis, S., Rasch, P.J., Yoshikitha, M., Zender, C.S., Luo, C., 2006. Change in atmospheric mineral aerosols in response to climate: Last glacial period, pre-industrial, modern and doubled carbon dioxide climates. Journal of Geophysical Research 111, D10202. doi:10.1029/2005JD006653.

Makeyev, V.M., Ponomareva, D.P., Pitulko, V.V., Chernova, G.M., Solovyeva, D.V., 2003. Vegetation and climate of the New Siberian Islands for the past 15,000 Years. Arctic. Antarctic and Alpine Research 35, 56-66.

Melnikov, V.P., Spesivtsev, V.I., 2000. Cryogenic Formations in the Earth's Lithosphere. Nauka, Novosibirsk, Russia, 343 p.

Meyer, H., Dereviagin, A.Y., Siegert, C., Hubberten, H.-W., 2002a. Paleoclimate studies on Bykovsky Peninsula, North Siberia-hydrogen and oxygen isotopes in ground ice. Polarforschung 70, 37-51.

Meyer, H., Dereviagin, A., Siegert, C., Schirrmeister, L., Hubberten, H.-W., 2002b. Palaeoclimate reconstruction on Big Lyakhovsky Island, North Siberia hydrogen and oxygen isotopes in ice wedges. Permafrost and Periglacial Processes 13, 91-105.

Mikulenko, K.I., 1996. Questions of the geology of the arctic region of West Yakutia. In: Grigoriev, M.N., Imaev, V.S., Imaeva, L.P.(Eds.), Geology, Seismicity and Permafrost Processes of the Arctic Region of West Yakutia Yakutsk, Russia, (in Russian).

Morozova, T.D., Velichko, A.A., 1996. Loess-ice formation in Northeastern Asia. In: West, C.F. (Ed.), American Beginnings: The Prehistory and Palaeoecology of Beringia. University of Chicago Press, Chicago and London, pp. 52-57.

Müller, S., Bobrov, A.A., Schirrmeister, L., Andreev, A.A., Tarasov, P.E., 2009. Testate amoebae record from the Laptev Sea coast and its implication for the reconstruction of Late Pleistocene and Holocene environments in the Arctic Siberia. Palaeogeography, Palaeoclimatology, Palaeoecology 271 (3-4), 301-315.

Mursaev, E.M., 1984. Glossary of Local Geographical Terms. Mysl Publishing House, Moscow, 653 pp. (in Russian).

Nadeau, M.J., Schleicher, M., Grootes, P.M., Erlenkeuser, H., Gottdang, A., Mous, D.J. W., Sarntheim, J.M., Willkomm, H., 1997. The Leibniz-Labor facility at the Christian-Albrecht-University, Kiel, Germany. Nuclear Instruments and Methods in Physics Research 123, 22-30.

Nadeau, M.J., Grootes, P.M., Schleicher, M., Hasselberg, P., Rieck, A., Bitterling, M., 1998. Sample throughput and data quality at the Leibniz-Labor AMS facility. Radiocarbon 40, 239-245.

Nagaoka, D., 1994. Properties of Ice Complex deposits in Eastern Siberia. In: Proceedings of the 2nd Symposium on the Joint Siberian Permafrost Studies between Japan and Russia in 1993, pp. 14-18. Tsukuba, Japan.

Nagaoka, D., Saijo, K., Fukuda, M., 1995. Sedimental environment of the Edoma in high Arctic eastern Siberia. In: Takahashi, K., Osawa, A., Kanazawa, Y. (Eds.), Proceedings of the 3rd Symposium on the Joint Siberian Permafrost Studies between Japan and Russia. Hokkaido University, Tsukuba, Japan, pp. 8-13.

Nikolskiy, P.A., Basilyan, A.E., Simakova, A.N., 1999. New data on stratigraphy of Upper Cenozoic deposits of Sviatoj Nos (Laptev Sea). In: Gribchenko, Yu.N., Nikolaev, V.I. (Eds.), Landscape-Climatic Changes, Animals and Man during the Last Pleistocene and Holocene, Moscow, pp. 51-60 (in Russian).

Nikolskiy, P.A., Basilyan, A.E., 2004. Svyatoy Nos - The main Quaternary cross section of the Yana-Indigirka lowland. In: Nikolskiy, P.-A., Pitulko, V.V. (Eds.), Natural History of the Russian Arctic during the Late Pleistocene and Holocene: Paleogeography, Geology and Archeology. GEOS Press, Moscow, pp. 5-13 (in Russian).

Overduin, P.P., Grigoriev, M.N., Junker, R., Rachold, V., Kunitsky, V.V., Bolshiyanov, D. Yu., Schirrmeister, L., 2007. Russian-German Cooperation System Laptev Sea: The Expedition COAST I: COAST Drilling Campaign 2005: Subsea permafrost studies in the near-shore zone of the Laptev Sea. In: Schirrmeister, L. (Ed.), Expeditions in Siberia 2005. Reports on Polar and Marine Research 550, 1-39.

Pye, K., 1984. Loess. Progress in Physical Geography 8, 176.

Péwé, T.L., Journaux, A., Stuckenrath, R., 1977. Radiocarbon dates and late Quaternary stratigraphy from Mamontova Gora, unglaciated Yakutia, Siberia, USSR. Quaternary Research 8, 51-63.

Péwé, T.L., Journaux, A., 1983. Origin and character of loess-like silt in unglaciated south-central Yakutia, Siberia, USSR. USGS Professional Paper 1262, 1-45.

Popov, A.I., 1967. Permafrost Phenomena in the Earth Crust (Cryolithology). MSU Publishing House, Moscow, 304 pp (in Russian).

Romanovskii, N.N., 1958a. New data about Quaternary deposits structure on the Bol'shoy Lyakhovsky Island (Novosibirskie Islands). Nauchnye Doklady Vysshei Shkoly. Seriya geologo-geograficheskaya 2, 243-248 (in Russian).

Romanovskii, N.N., 1958b. Paleogeographic conditions of formation of the Quaternary deposits on Bol'shoy Lyakhovsky Island (Novosibirskie Islands). In: Bogorov, V.G. (Ed.), Voprosy fizicheskoi geografii polyarnykh stran. Vypysk I. Moscow State University, Moscow, pp. 80-88 (in Russian).

Romanovskii, N.N., 1958c. Permafrost structures in Quaternary deposits. Nauchnye Doklady Vysshei Shkoly. Seriya geologo-geograficheskaya 3,185-189 (in Russian).

Romanovsky, N.N., 1993. Fundamentals of the Cryogenesis of the Lithosphere. University Press, Moscow, pp. 1-336 (in Russian).

Rozenbaum, G.E., 1981. Special features of lithogenesis of the alluvial planes in the Eastern Subarctic as related to the problem of the Ice (Yedoma) Complex. In: Problems of Cryolithology, vol. 9. MSU Press, Moscow. 87-100 (In Russian).

Schirrmeister, L., Kunitsky, V., Grosse, V., Meyer, H., Kuznetsova, T., Kuzmina, S. Tumskoy, V., Derevyagin, A., Akhmadeeva, I., Syromyatnikov, I., 2000. Quaternary deposits of Bol'shoy Lyakhovsky Island. Reports on Polar Research 354, 113-168. Alfred Wegener Institute for Polar and Marine Research, Bremerhaven.
Schirrmeister, L., Kunitsky, V.V., Grosse, G., Kuznetsova, T., Kuzmina, S. Bolshiyanov, D., 2001. Late Quaternary and recent environmental situation around the Olenyok Channel (western Lena Delta) and on Bykovsky Peninsula. Reports on Polar Research 388, 85-135.

Schirrmeister, L., Siegert, C., Kuznetsova, T., Kuzmina, S., Andreev, A.A., Kienast, F., Meyer, H., Bobrov, A. 2002a. Paleoenvironmental and paleoclimatic records from permafrost deposits in the Arctic region of Northern Siberia. Quaternary International 89, 97-118.

Schirrmeister, L., Siegert, C., Kunitsky, V.V., Grootes, P.M., Erlenkeuser, H., 2002b. Late Quaternary ice-rich permafrost sequences as a paleoenvironmental archive for the Laptev Sea region in northern Siberia. International Journal of Earth Sciences 91, 154-167.

Schirrmeister, L., Oezen, D., Geyh, M.A., 2002c. ${ }^{230} \mathrm{Th} / \mathrm{U}$ dating of frozen peat, Bol'shoy Lyakhovsky Island (North Siberia). Quaternary Research 57, 253-258.

Schirrmeister, L., Grosse, G., Kunitsky, V., Meyer, H., Derevyagin, A., Kuznetsova, T. 2003a. Permafrost, periglacial and paleo-environmental studies on New Siberian Islands. Reports on Polar Research 466, 195-314.

Schirrmeister, L., Grosse, G., Schwamborn, G., Andreev, A.A., Meyer, H., Kunitsky, V. V., Kuznetsova, T.V., Dorozhkina, M.V., Pavlova, E.Y., Bobrov, A.A., Oezen, D. 2003b. Late Quaternary history of the accumulation plain north of the Chekanovsky Ridge (Lena Delta, Russia): a multidisciplinary approach. Polar Geography $27,277-319$.

Schirrmeister, L. (Ed.), 2004. Periglacial studies around Cape Mamontov Klyk. In: Schirrmeister, L, Grigoriev, M.N., Kutzbach, L., Wagner, D., Bolshiyanov, D.Yu. (Eds.) 2004. Russian-German Cooperation SYSTEM LAPTEV SEA: The Expedition Lena-Anabar 2003. Reports on polar and marine research, 489, 61-209.

Schirrmeister, L. (Ed.), 2007. Studies of periglacial landscape dynamics and surface characteristics studies in the western Lena Delta. In: Schirrmeister, L., Wagner D., Grigoriev, M.N., Bolshiyanov, D.Y. (Eds.), The Expedition LENA 2005, Expeditions in Siberia in 2005. Reports on Polar and Marine Research 550, 83-196.

Schirrmeister, L., Grosse, G., Kunitsky, V., Magens, D., Meyer, H., Dereviagin, A., Kuznetsova, T., Andreev, A., Babiy, O., Kienast, F., Grigoriev, M., Overduin, P.P. Preusser, F., 2008a. Periglacial landscape evolution and environmental changes of Arctic lowland areas for the last 60,000 years (Western Laptev Sea coast, Cape Mamontov Klyk). Polar Research 27 (2), 249-272. doi:10.1111/j.17518369.2008.00067.x.

Schirrmeister, L., Wetterich, L., Tumskoy, V., Dobrynin, D., 2008b. Palaeoenviromental studies on Bol'shoy Lyakhovsky Island. In: Boike, J. Bolshiyanov, D., Schirrmeister, L., Wetterich, S. (Eds.), Russian-German Cooperation System Laptev Sea: The Expedition Lena - New Siberian Islands 2007 (during the International Polar Year 2007/2008). Reports on Polar and Marine Research 584, 51-84.

Schuur, E.A.G., Bockheim, J., Canadell, J.G., Euskirchen, E., Field, C.B., Goryachkin, S. V., Hagemann, S., Kuhry, P., Lafleur, P.M., Lee, H., Mazhitova, G., Nelson, F.E. Rinke, A., Romanovsky, V.E., Shiklomanov, N., Tarnocai, C., Venevsky, S., Vogel, J G., Zimov, S.A., 2008. Vulnerability of permafrost carbon to climate change: Implications for the global carbon cycle. BioScience 58 (8), 701-714.

Schwamborn, G., Schneider, W., Grigoriev, M.N., Rachold, V., Antonow, M., 1999. Sedimentation and environmental history of the Lena Delta. In: Rachold, V., Grigoriev, M.N. (Eds.), Russian-German Cooperation System Laptev Sea 2000 The Lena Delta 1998 Expedition. Reports on Polar Research 315, 94-111.

Schwamborn, G., Rachold, V., Grigoriev, M.N., 2002. Late Quaternary sedimentation history of the Lena Delta. Quaternary International 89, 119-134.

Seppälä, M., 2004. Wind as a geomorphic agent in cold climates. Studies in Polar Research. Cambridge University Press, 358 pp.

Sher, A.V., Kaplina, T.N., Ovander, M.G., 1987. Unified regional stratigraphic chart for the Quaternary deposits in the Yana-Kolyma Lowland and its mountainous surroundings. Explanatory note. In: Decisions of Interdepartmental Stratigraphic Conference on the Quaternary of the Eastern USSR. Magadan, 1982 USSR Academy of Sciences, Far-Eastern Branch, North-Eastern Complex Research Institute, Magadan, USSR, pp. 29-69 (in Russian).

Sher, A.V., 1997. A brief overview of the Late-Cenozoic history of the Western Beringian Lowlands. In: Edwards, M.E., Sher, A.V., Guthrie, R.D. (Eds.), Terrestria paleoenvironmental studies in Beringia, Proceedings of a joint Russian-American workshop, Fairbanks, Alaska, June 1991, pp. 3-6.

Sher, A., Parmuzin, I., Bartsov, A., 2000. Ice Complex on Bykovsky Peninsula. AWI Reports on Polar and Marine Research 354, 169-182.

Sher, A., Kuzmina, S., Kiselyov, S., Lister, A., 2003. . Tundra-steppe environment in arctic Siberia and the evolution of the woolly mammoth. In: The Third International Mammoth Conference, Yukon, Canada, May 24-29, 2003, pp. 136-142. Abstracts.

Sher, A.V., Kuzmina, S.A., Kuznetsova, T.V., Sulerzhitsky, L.D., 2005. New insights into the Weichselian environment and climate of the East Siberian Arctic, derived from fossil insects, plants, and mammals. Quaternary Science Reviews $24,533-569$

Siegert, C., Schirrmeister, L., Kunitsky, V.V., Meyer, H., Kuznetsova, T., Dereviagyn, A. Kuzmina, S., Tumskoy, V., Sher, A., 1999. Paleoclimate signals of ice-rich permafrost. AWI Reports on Polar and Marine Research 315, 145-259.

Siegert, C., Schirrmeister, L., Babiy, O., 2002. The sedimentological, mineralogical and geochemical composition of late Pleistocene deposits from the ice complex on the Bykovsky Peninsula, northern Siberia. Polarforschung 70, 3-11.

Slagoda, E.A., 1993. Genesis i mikrostroenie kriolitogennykh otlozhenii Bykovskogo polyostrova i ostrova Muoastakh [Genesis and microstructure of cryolithogenic deposits at the Bykovsky Peninsula and the Muostakh Island]. Ph.D. Thesis. Russian Academy of Science, Siberian Branch, Permafrost Institute Yakutsk (in Russian). 
Slagoda, E.A., 2004. Cryolithogenic Deposits of the Laptev Sea Coastal Plain: Lithology and Micromorphology. Publishing and Printing Centre Express, Tyumen, 119 pp. (in Russian).

Solomatin, V.N., 1974. Composition and origin of polygonal ice wedges in Pleistocene deposits of Northern Yakutia (according to study results of the Yana Omoloy interfluve and Muostakh Island). In: Problems of Cryolithology, vol. 4. MSU Publishing House, Moscow (in Russian).

Soloviev, P.A., 1959. The cryolithozone in the north part of the Lena-Amga-Interfluve. Academy of Science of the USSR, $144 \mathrm{pp}$. (in Russian).

Svendsen, J.I., Alexanderson, H., Astakhov, V.I., Demidov, I., Dowdeswell, J.A., Funder, S., Gataullin, V., Henriksen, M., Hjort, C., Houmark-Nielsen, M., Hubberten, H.-W., Ingolfsson, O., Jacobsson, M., Kjær, K., Larsen, E., Lokrantz, H., Lunkka, J.P., Lysa, A., Mangerud, J., Matioushkov, A., Murray, A., Moeller, P., Niessen, F., Nikolskaya, O., Polyak, L., Saarnisto, M., Siegert, C., Siegert, M.J., Spielhagen, R.F., Stein, R., 2004. Late Quaternary ice sheet history of northern Eurasia. Quaternary Science Reviews 23, 1229-1272.

Tarnocai, C., Canadell, J.G., Schuur, E.A.G., Kuhry, P., Mazhitova, G., Zimov, S., 2009. Soil organic carbon pools in the northern circumpolar permafrost region. Global Biogeochemical Cycles 23, GB2023.

Thorn, C.E., Hall, K., 2002. Nivation and cryoplanation: the case for scrutiny and integration. Progress in Physical Geography 26 (4), 533-550.

von Toll, E.V., 1895. Wissenschaftliche Resultate der von der Kaiserlichen Akademie der Wissenschaften zur Erforschung des Janalandes und der Neusibirischen Inseln in den Jahren 1885 und 1886 ausgesandten Expedition. Abtheilung 3. Die fossilen Eislager und ihre Beziehungen zu den Mammuthleichen. In: Mémoires de L'Académie impérials des Sciences de St. Pétersbourg VII Série, Tome XLIl, No. 13. Commissionnaires de l'Académie Impériale des Sciences, St. Pétersbourg. $1-86$.

Tomirdiaro, S.V., 1970. Eolian-cryogene origin of Yedoma-Complex deposits of Northeast USSR. Abstracts of the Allunion Permafrost Conference. Moscow State University, Moscow, pp. 106-107 (in Russian).

Tomirdiaro, S.V., 1980. Loess-ice Formations of East Siberia During Late Pleistocene and Holocene. Nauka Press, Moscow, 184 pp. (in Russian).

Tomirdiaro, S.V., 1982. Evolution of lowland landscapes in northern Asia during Late Quaternary time. In: Hopkins, D.V., Matthews Jr., J.V., Schweger, Ch.E. Young, S.B. (Eds.), Paleoecology of Beringia. Academic Press, New York, NY, pp. $29-37$.

Tomirdiaro, S.V., 1984. Periglacial landscape and loess accumulation in the late Pleistocene Arctic and Subarctic. In: Velichko, A.A., Wright Jr., H.E., Barnosky, C. W. (Eds.), Late Quaternary Environments of the Soviet Union. University of Minnesota Press, Minneapolis, MN, pp. 141-146.
Tomirdiaro, S.V., Arslanov, K.A., Chernen'kii, B.I., Tertychnaya, T.V., Prokhorova, T.N., 1984. New data on formation of loess-ice sequences in Northern Yakutia and ecological conditions of mammoth fauna in the Arctic during the late Pleistocene. Reports Academy of Sciences USSR 278, 1446-1449 (in Russian).

Tomirdiaro, S.V., Chernen'k'ii, B.I., 1987. Cryogenic deposits of East Arctic and Sub Arctic. AN SSSR Far-East-Science Center, Magadan, pp. 1-196 (in Russian).

Tomirdiaro, S.V., 1996. Palaeogeography of Beringia and Arctida. In: West, C.F. (Ed.), American Beginnings: The Prehistory and Palaeoecology of Beringia. University of Chicago Press, Chicago and London, pp. 58-69.

Trask, P.D., 1932. Origin and environment of source sediments of petroleum. Gulf Publ. Co., Houston, Texas, 323 pp.

Walter, K.M., Zimov, S.A., Chanton, J.P., Verbyla, D., Chapin III, F.S., 2006. Methane bubbling from Siberian thaw lakes as a positive feedback to climate warming. Nature 443, 71-75.

Walter, K.M., Edwards, M.E., Grosse, G., Zimov, S.A., Chapin III, F.S., 2007. Thermokarst lakes as a source of atmospheric $\mathrm{CH}_{4}$ during the last deglaciation. Science 318, 633-636.

Washburn, A.L., 1979. Geocryology - A Survey of Periglacial Processes and Environments. Edward Arnold Ltd., London, UK, 406 p.

Wetterich, S., Schirrmeister, L., Pietrzeniuk, E., 2005. Freshwater Ostracodes in Quaternary permafrost deposits in the Siberian Arctic. Journal of Paleolimnology 34, 363-374. doi:10.1007/s10933-005-5801-y.

Wetterich, S., Kuzmina, S., Andreev, A.A., Kienast, F., Meyer, H., Schirrmeister, L., Kuznetsova, T., 2008. Palaeoenvironmental dynamics inferred from late Quaternary permafrost deposits on Kurungnakh Island, Lena Delta, Northeast Siberia, Russia. Quaternary Science Reviews 27 (15-16), 1523-1540. doi:10.1016/j.quascirev.2008.04.007.

Wetterich, S., Schirrmeister, L., Andreev, A.A, Pudenz, M. Plessen, B., Meyer, $\mathrm{H}$, Kunitsky, V.V., 2009. Eemian and Late Glacial/Holocene palaeoenvironmental records from permafrost sequences at the Dmitry Laptev Strait (NE Siberia, Russia). Paleogeography, Paleoclimatology, Paleoecology 279 (1-2), 73-95. doi:10.1016/j.palaeo.2009.05.002.

Winterfeld, M., Schirrmeister, L., Grigoriev, M.N., Kunitsky, V.V., Andreev, A.A., Overduin, P.P. Permafrost and landscape dynamics during the Late Pleistocene, Western Laptev Sea Shelf, Siberia, Boreas, under review.

Yershov, E.D. (Ed.), 1989. Geocryology of the USSR, East Siberia and Far East. "Nedra” Publishing House, Moscow, 515 pp.

Zimov, S.A., Schuur, E.A.G., Chapin III, F.S., 2006. Permafrost and the global carbon budget. Science 312,1612-1613. doi:10.1126/science.1128908. 